\title{
Structural evolution and medium-temperature thermochronology of central Madagascar: implications for Gondwana amalgamation
}

\section{Sheree E. Armistead ${ }^{\mathrm{a}, \mathrm{b}, \mathrm{c}^{*}}$, Alan S. Collins ${ }^{\mathrm{a}}$, Ahmad Redaa ${ }^{\mathrm{a}, \mathrm{d}}$, Gilby Jepson $^{\mathrm{a}, \mathrm{e}}$, Jack Gillespie ${ }^{\mathrm{a}, \mathrm{f}}$, Sarah Gilbert $^{\mathrm{g}}$, Morgan L. Blades ${ }^{\mathrm{a}}$, John D. Foden ${ }^{\mathrm{a}}$, Théodore Razakamananah}

aTectonics \& Earth Systems Research Group, Mawson Centre for Geoscience, Department of Earth Sciences, University of Adelaide, SA, Australia

bGeological Survey of Canada, 601 Booth Street, Ottawa, Ontario, Canada

cMetal Earth, Harquail School of Earth Sciences, Laurentian University, Sudbury, Ontario, Canada

dFaculty of Earth Sciences, King Abdulaziz University, Jeddah, Saudi Arabia

eDepartment of Geosciences, University of Arizona, 1040 E. $4^{\text {th }}$ Street, Tucson, Arizona, USA

fThe Institute for Geoscience Research (TIGeR), School of Earth and Planetary Sciences, Curtin University, Perth, Australia gAdelaide Microscopy, University of Adelaide, Adelaide, SA, Australia

hDépartement des Sciences de la Terre, Université de Toliara, Toliara, Madagascar

*correspondence (sheree.armistead@adelaide.edu.au)

This manuscript has been accepted in the JOURNAL OF THE GEOLOGICAL SOCIETY.

Previous versions of this manuscript are available at doi.org/10.31223/osf.io/x46vc

Version history:

Version 1: $\quad$ Submitted $18^{\text {th }}$ December 2018;

Rejected with invitation to resubmit $11^{\text {th }}$ March 2019 :

Version 2: $\quad$ Submitted $19^{\text {th }}$ August 2019;

Major revision returned $19^{\text {th }}$ October 2019 ;)

Version 3: $\quad$ Revised submission $16^{\text {th }}$ December 2019;

Minor revisions returned $15^{\text {th }}$ January 2020;

Revised submission $28^{\text {th }}$ January 2020;

ACCEPTED $1^{\text {st }}$ February 2020 !! :) : 


\section{Abstract}

Madagascar occupied an important place in the amalgamation of Gondwana and preserves a record of several Neoproterozoic events that are linked to orogenesis of the East African Orogen. In this study, we integrate remote sensing, field data and thermochronology to unravel complex deformation in the Ikalamavony and Itremo domains of central Madagascar. The deformation sequence comprises a gneissic foliation (S1), followed by south to south-west directed, tight to isoclinal, recumbent folding (D2). These are overprinted by north-trending upright folds that formed during an $\sim \mathrm{E}-\mathrm{W}$ shortening event (D3). Together these produced type 1 and type 2 fold interference patterns throughout the Itremo and Ikalamavony domains. We show that the Itremo and Ikalamavony domains were deformed together in the same orogenic system, which we interpret as the c. 630 Ma collision of Azania with Africa along the Vohibory Suture in southwestern Madagascar. In eastern Madagascar, deformation is syn- to post-550 Ma, which likely formed in response to final closure of the Mozambique Ocean along the Betsimisaraka Suture that amalgamated Madagascar with the Dharwar Craton of India. Apatite U$\mathrm{Pb}$ and novel LA-QQQ-ICP-MS muscovite and biotite $\mathrm{Rb}-\mathrm{Sr}$ thermochronology indicate that much of central Madagascar cooled through $\sim 500^{\circ} \mathrm{C}$ at c. $500 \mathrm{Ma}$.

Keywords: thermochronology, Gondwana, remote sensing, GIS, supercontinents

\section{Supplementary material:}

Supplementary A: Detailed geological map of central Madagascar

Supplementary B: Detailed methodology and geo/thermochronology results

Supplementary C: Isotopic data for geo/thermochronology

Supplementary D: Landsat images and structural interpretation examples

\section{Introduction}

The amalgamation of central Gondwana occurred through convergence at several discrete subduction and collisional zones; collectively forming the East African Orogen. Madagascar was located in the centre of Gondwana and provides an ideal natural laboratory to study how this supercontinent coalesced (Figure 1a) (Collins, 2006; Collins and Windley, 2002; Tucker et al., 1999). Of particular interest and contention, is how and when the Archean nucleus of Madagascar amalgamated with the Dharwar Craton of India to the east, and East Africa to the west, as well as smaller continental blocks of equivocal origin. Reconciling this tectonic history has major implications for global plate tectonic models of the Neoproterozoic (e.g. Merdith et al., 2017).

Central Madagascar comprises the Archean Antananarivo Domain, the Proterozoic Itremo sub-domain and the Neoproterozoic Ikalamavony Domain. These terranes are bound by two postulated major sutures; the eastern Betsimisaraka Suture and the western Vohibory Suture (mapped as the Ampanihy shear zone in Figure 1b). These sutures resulted from at least two distinct orogenic events that amalgamated central Madagascar, the Dharwar Craton of India, and Africa within Gondwana (Figure 
1a). However, the timing, location, and direction of subduction leading to these orogenic events remain contentious. Two end-member models are generally evaluated for the amalgamation of Madagascar; 1) that the Dharwar-central Madagascar collision (eastern suture) occurred in the late Archean, and that central Madagascar and the Dharwar craton existed as the "Greater Dharwar Craton" through the entire Proterozoic eon (Tucker et al., 2011), and that widespread NeoproterozoicCambrian magmatism and metamorphism in Madagascar resulted from Madagascar-Africa collision (western suture); or 2) that the Dharwar Craton and central Madagascar were separate terranes that were sutured during a major Ediacaran-Cambrian East African orogenic event (the Malagasy Orogeny of Collins and Pisarevsky 2005), marked by the Betsimisaraka Suture in eastern Madagascar (Figure 1b). An age of c. 750-650 Ma for this suture has alternatively been proposed (Fitzsimons and Hulscher, 2005). Several authors have proposed that the central Madagascar-Africa collision occurred at c. 650$630 \mathrm{Ma}$ (Collins and Pisarevsky, 2005; Collins and Windley, 2002; Emmel et al., 2008; Horton et al., 2016; Jöns and Schenk, 2011). Other authors have suggested a c. 850-750 Ma age for a suture in western Madagascar (Moine et al., 2014). The proximity of these two suture zones makes it difficult to unravel the timing of events, as more recent events have obscured the record of earlier events through high temperature resetting of key minerals used for thermochronology and metamorphism.

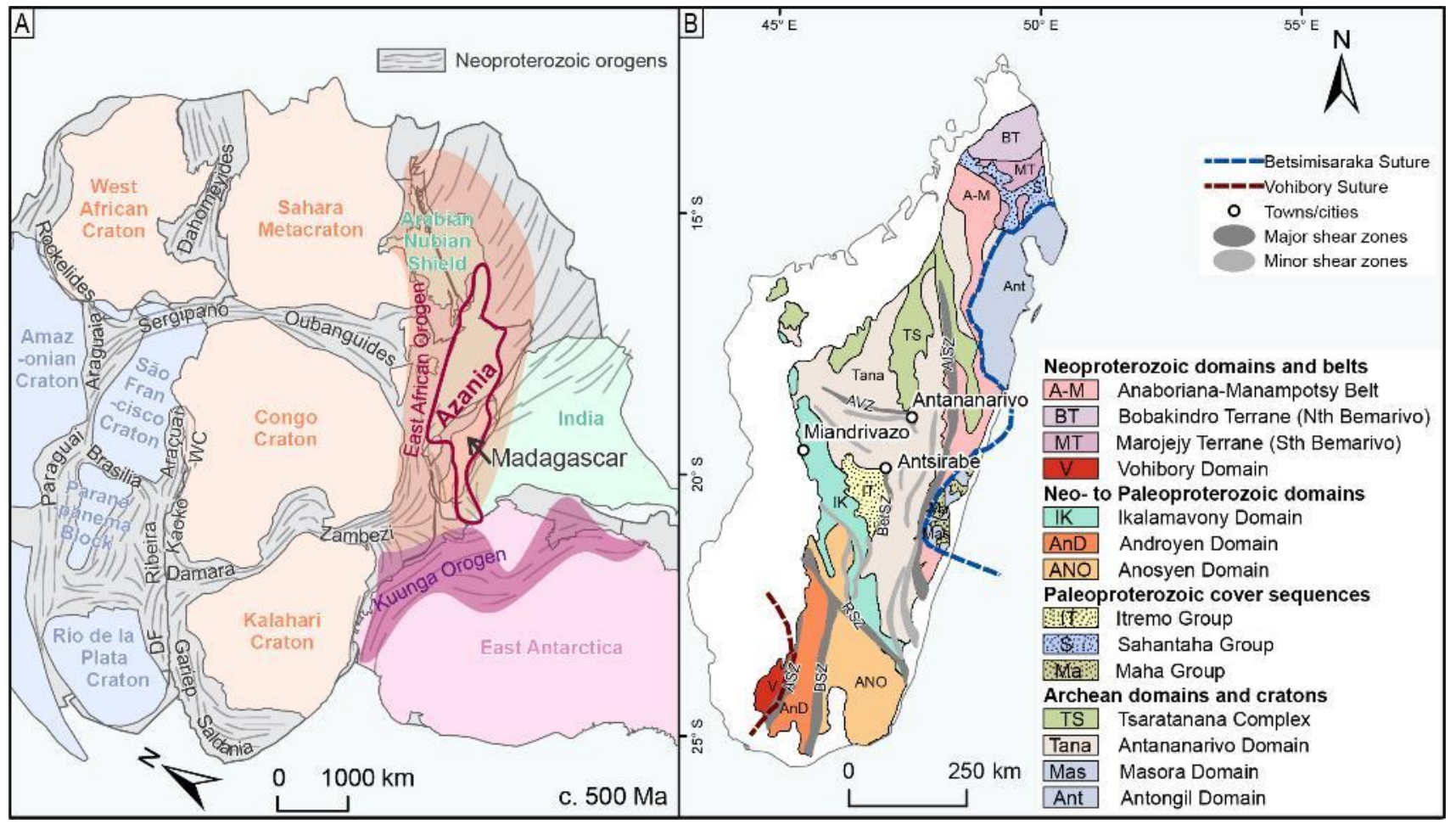

Figure 1 a) Tectonic map of Gondwana made using GPlates exported geometries from Merdith et al. (2017) in ArcGIS; projected in Hotine Oblique Mercator with Madagascar in the centre (reconstructed position, longitude $=-75^{\circ}$ and latitude $=+40^{\circ}$ ). DF=Dom Feliciano Belt, WC=West Congo; b) Present day map of the geological domains of Madagascar after De Waele et al. (2011). AISZ=Angavo-Ifanadiana shear zone, AVZ=Antananarivo virgation zone, BetSZ=Betsileo shear zone, RSZ=Ranotsara shear zone, BSZ=Beraketa shear zone, ASZ=Ampanihy shear zone. 


\subsection{Regional geology}

6o Madagascar is made up of several domains ranging in age from Archean to Neoproterozoic (Figure 1b).

61 The centre of Madagascar is made up of the Antananarivo Domain, which has a basement of c. 2500

62 Ma magmatic gneisses (Collins and Windley, 2002; Kröner et al., 2000; Tucker et al., 1999), known as

63 the Betsiboka Suite (Roig et al., 2012), interleaved with the Ambatolampy Group granulite- and

64 amphibolite-facies metasedimentary rocks (Archibald et al., 2015). To the east of the Antananarivo

65 Domain is the Antongil-Masora Domain, which contains gneisses that are c. 3100 Ma and c. 2500 Ma,

66 and are interpreted as a continuation of the Dharwar Craton of India (Armistead et al., 2017; Schofield

67 et al., 2010; Tucker et al., 1999).

68 Overlying the Antananarivo Domain is the Itremo Group (Figure 1b; Figure 2). Classified as a subquartzites, schists and marbles with a maximum depositional age of c. $1600 \mathrm{Ma}$ (Cox et al., 1998; Fernandez et al., 2003). The Itremo Group is interpreted as a continental margin sequence that was deposited on the Antananarivo Domain basement (Cox et al., 1998; 2004). The Itremo nappes in the Itremo Domain have been investigated extensively due to their prominence in remotely sensed data and availability of outcrops (Collins et al., 2003b; Tucker et al., 2007).

To the southwest, thrust over the Itremo Group, is the Ikalamavony Group within the Ikalamavony Domain, similarly made up of quartzites, schists and marbles but with a maximum depositional age of c. $1000 \mathrm{Ma}$ (Archibald et al., 2017a; Tucker et al., 2014). In places the Ikalamavony Domain is in tectonic contact directly with the Antananarivo Domain basement, with no Itremo Group rocks separating them (Figure 1b; Figure 2). Unique to the Ikalamavony Domain is the c. 1000 Ma Dabolava Suite, which is composed of granitic to gabbroic orthogneiss (Archibald et al., 2017a). The Dabolava Suite and the age-equivalent Ikalamavony Group have been interpreted as an oceanic arc terrane (Archibald et al., 2017a). This terrane must have accreted prior to the intrusion of the c. 850-750 Ma Imorona-Itsindro Suite, which intrudes the Ikalamavony, Itremo and Antananarivo domains-placing a minimum age on the juxtaposition of the three central Madagascan domains. The relationship between the Ikalamavony Domain and the Itremo Group remains poorly understood, and is the focus of this study.

To the south of these metasedimentary terranes are the Proterozoic Anosyen, Androyen and Vohibory domains (Boger et al., 2014; de Wit et al., 2001; Emmel et al., 2008; Horton et al., 2016; Jöns and Schenk, 2008). In northern Madagascar is the c. 800-700 Ma Bemarivo Domain, which formed as an exotic juvenile arc terrane that amalgamated with Madagascar at c. $520 \mathrm{Ma}$, possibly in relation to the Betsimisaraka Suture (Armistead et al., 2019; Jöns et al., 2009; Thomas et al., 2009).

\subsection{Regional structural and geochronological framework for central Madagascar}

This study focuses on central Madagascar including parts of the Ikalamavony, and Antananarivo domains and the Itremo sub-domain (Figure 1b, Figure 2). The structural relationships between these domains has not yet been studied in detail. We use structural geology and various geochronological methods to define and distinguish deformation events in central Madagascar. Collins et al. (2003b) and 
97 Tucker et al. (2007) undertook comprehensive studies of the structure of the Itremo Group in central

98 Madagascar. This area contains spectacularly folded sequences visible from satellite imagery. Collins et

99 al. (2003b) interpreted a D1 event that produced $10 \mathrm{~km}$ scale recumbent, isoclinal folding predating c. $100 \quad 800-780$ Ma intrusive rocks of the Imorona-Itsindro Suite. D2 was interpreted as a local deformation 101 event that occurred synchronously with c. 800-780 Ma intrusions. D3 was interpreted as an east-west 102 shortening event with thrusting and at least two phases of upright folding. D4 is expressed as post-550 103 Ma normal shearing and locally marks the boundary between the least metamorphosed parts of the 104 Itremo Group and the granulite-facies Betsiboka Suite and Ambatolampy Group of the Antananarivo 105 Domain (Betsileo Shear Zone; Figure 1b; Collins et al. 2000). Tucker et al. (2007) interpreted a similar 106 history for the Itremo Group with km-scale fold and thrust nappes, and east-directed vergence. This 107 resulted in inversion and repetition of the Archean Antananarivo Domain gneisses and the Proterozoic 108 Itremo Group, with high-grade (old) rocks being thrust over low-grade (young) rocks. The inversion 109 was followed by east-west shortening that resulted in upright folding of nappes to produce km-scale 110 fold interference patterns. This shortening event occurred within a sinistral transpressive regime and was interpreted as being associated with the Ranotsara Shear Zone (Figure 1b) in southern Madagascar (Tucker et al., 2007). Although these models are similar in their sequence and style of deformation, they differ in that Tucker et al. (2007) interpreted the timing of deformation as occurring after c. 720 Ma, whereas Collins et al. (2003b) interpreted the early nappes as forming before 800-780 Ma, and the upright folding having occurred after the c. 780 Ma intrusive rocks.

The region between the eastern-most part of our study area and the east coast of Madagascar (approximately the location of the Betsimisaraka Suture in Figure 1b) was studied from a structural perspective in Collins et al. (2003a); Martelat et al. (2000); Nédélec et al. (2000); Raharimahefa and Kusky (2006); Raharimahefa and Kusky (2009); Raharimahefa et al. (2013). Interpretations of this region generally include a D1 event characterised by N-S striking foliations that dip to the west, with a top to the east sense of movement (Collins et al., 2003a; Nédélec et al., 2000). These rocks are reworked by D2 shear zones such as the Angavo Shear Zone and the Antananarivo virgation zone (Figure 1b) that underwent low-pressure, granulite conditions (Nédélec et al., 2000; Paquette and Nédélec, 1998). D3 is characterised by $>20 \mathrm{~km}$ wide mylonitic high-strain zones and smaller discrete shear zones (Collins et al., 2003a). These dip gently to the west, with a top to the east sense of movement. D4 is characterised by poorly preserved late stage folding (Collins et al., 2003a). A syn-kinematic granite within the Angavo Shear Zone constrains deformation here to c. 550 Ma (Raharimahefa and Kusky, 2010). 


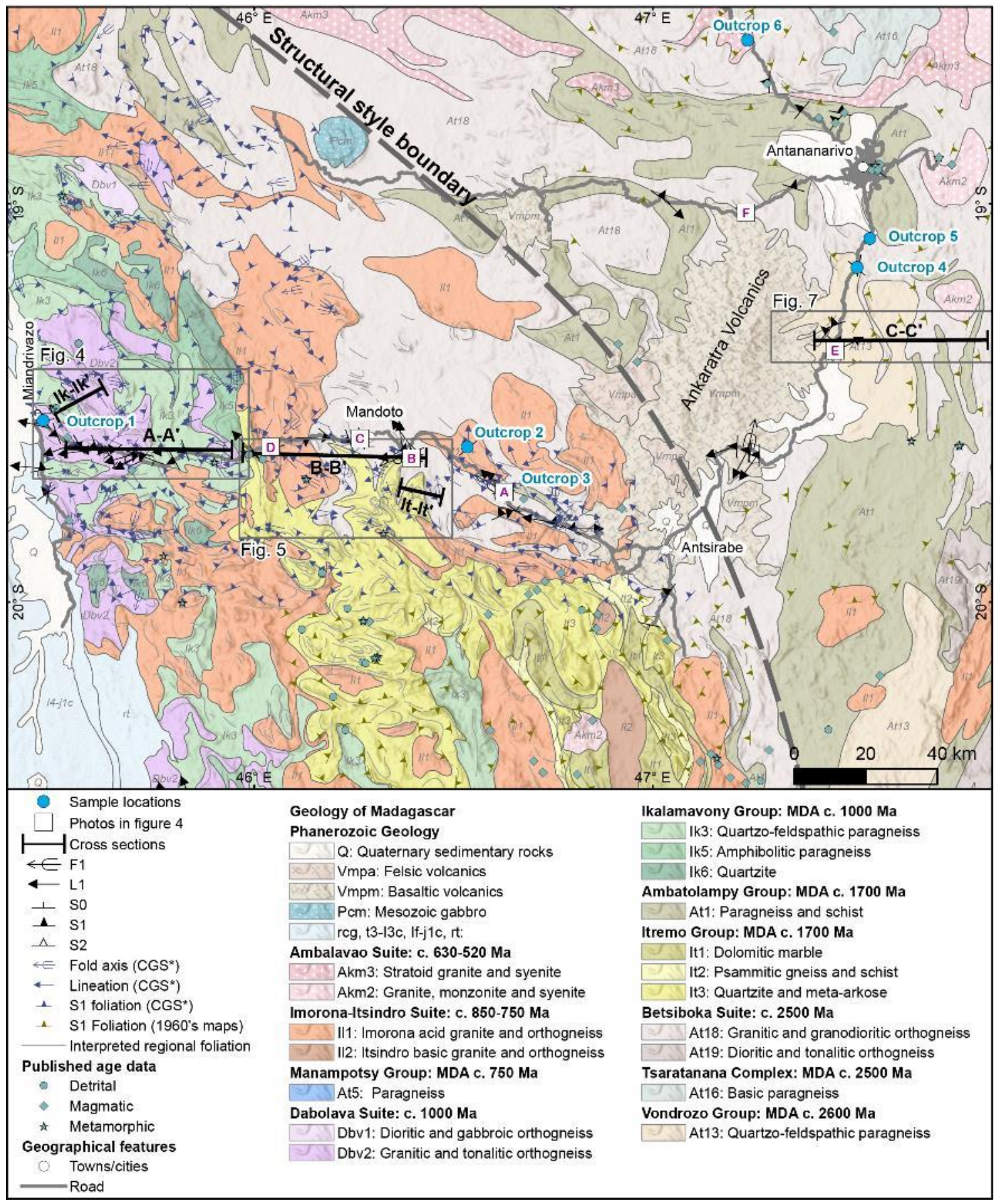

Figure 2 Geological map of central Madagascar (Roig et al., 2012) with sample locations, photo locations from Figure 6, our remote sensing interpretation, new structural measurements and structural measurements from Macey et al. (2009); Moine (1968); Service Géologique de Madagascar (1962); Service Géologique de Madagascar (1963a); Service Géologique de Madagascar (1963b), and published geochronology. Numbers associated with these points are provided in a detailed PDF copy of this map where layers can be turned on and off, and further information obtained from the model tree in a pdf viewer (Supplementary A).

Precise dating of deformation in Madagascar is difficult due to resetting from successive overlapping thermo-tectonic events. Latest metamorphism in the Anosyen and Androyen domains to the south of our study area is constrained to c. 580-520 Ma (Figure 3) (Collins et al., 2012; de Wit et al., 2001; Martelat et al., 2000; Paquette et al., 1994) and attributed to high-strain shearing along the Ampanihy and Beraketa shear zones (Figure 1b) (Boger et al., 2015; Boger et al., 2014). Horton et al. (2016); Jöns 
and Schenk (2011) demonstrated that in southern Madagascar, high-grade metamorphism yielded ages of c. 650-600 Ma west of the Vohibory Suture (Figure 3), but recorded ages of c. 560-530 Ma to the east of this suture. In central Madagascar, $\mathrm{U}-\mathrm{Pb}$ dating of zircon rims and titanite have been used to constrain latest metamorphism in the Itremo Group to c. 550-500 Ma (Tucker et al., 2007). Further east, between the eastern-most part of the study area and the east coast of Madagascar, metamorphism has been dated to c. 560-520 Ma (BGS-USGS-GLW, 2008; Collins et al., 2003c; Kröner et al., 2000). From this, it is clear that whatever event was taking place at c. 580-520 Ma, its effects were widespread and resulted in metamorphism throughout most of Madagascar, sparing, perhaps, the far southwest.

The cross-cutting relationships and deformation history of the rocks within the terranes that make up Madagascar can provide clues as to the timing of major orogenic events. Here we use structural geology to understand the deformation history of a poorly understood part of central Madagascar, which lies between the two hypothesised suture zones. We attempt to link up previous structural studies and further extend these interpretations to cover the entire central Madagascar region. We have used remotely sensed data such as satellite imagery and Landsat to interpret the structural framework of central Madagascar, and integrated existing geochronological and structural data (Supplementary A). We have ground-truthed this interpretation by collecting structural data and key rock samples for U$\mathrm{Pb}$ zircon, $\mathrm{U}-\mathrm{Pb}$ apatite, $\mathrm{Rb}-\mathrm{Sr}$ muscovite and $\mathrm{Rb}-\mathrm{Sr}$ biotite analysis (Supplementary $\mathrm{B}$; Supplementary C). $\mathrm{Rb}-\mathrm{Sr}$ mica laser ablation QQQ-ICP-MS dating in particular is a novel technique and this research represents some of the first published ages using this technique. These isotopic systems span a wide range of closure temperatures from which we can reconstruct the temporal and thermal evolution of this region.

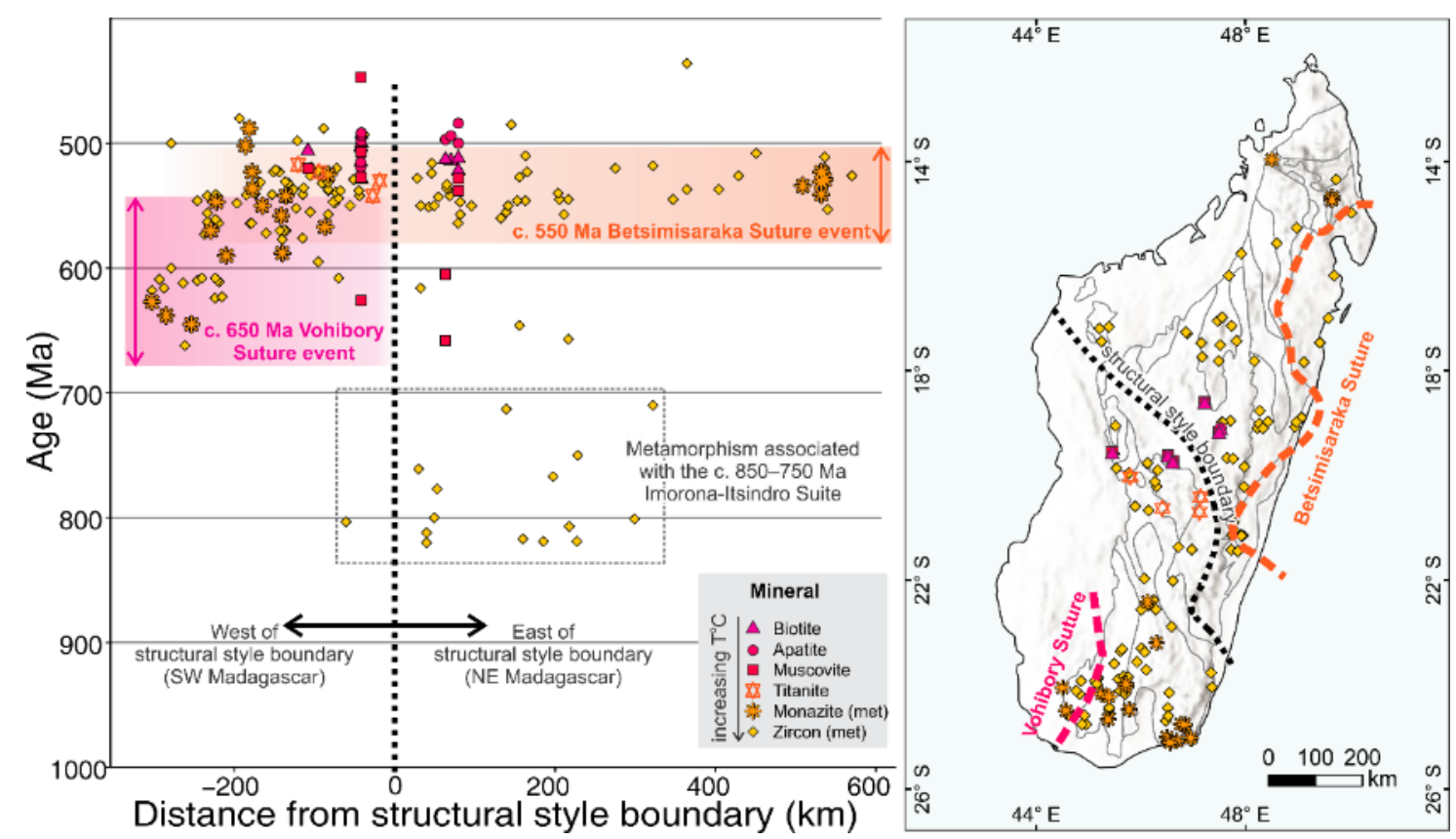




\section{Structure of central Madagascar}

167 Large-scale structures, fold interference patterns, faults and shear zones are recognisable in remotely 168 sensed data in the region west of Antsirabe (Figure 2). Examples of Landsat images used for interpretation are presented in Supplementary D. East of Antsirabe, polydeformed folds are not observed and the structural style changes significantly. We have delineated this as a 'structural style boundary' in Figure 2. Here we further extend previous interpretations of the Itremo sub-domain (Collins et al., 2003b; Tucker et al., 2007) to the Ikalamavony Domain, where identification of lithostratigraphy from remotely sensed data is more difficult, and interpretation is less straightforward.

\subsection{Ikalamavony Domain}

The Ikalamavony Domain contains metasedimentary rocks of the Ikalamavony Group, which are dominated by paragneiss, schist, quartzite and amphibolite (Figure 4). We observe many of the gneisses with bands of mylonite, indicating a high strain environment. Based on remote sensing data, we interpret a thrust fault separating the Ikalamavony Domain and Itremo sub-domain (Figure 5). This fault is interpreted based on the sharp contrast in lithologies and the linear nature of the fault observed in remote sensing data. Due to the scarcity of fresh outcrop, we were unable to observe this fault in the field, however rocks were more strongly deformed in this area.

\subsubsection{D1 Deformation}

The first recognisable deformation event at the outcrop scale is defined by a pervasive foliation observed in orthogneisses, paragneisses and metasedimentary rocks. In orthogneisses and paragneisses, the foliation is typically defined by the elongation and alignment of biotite, feldspar and quartz. In metasedimentary rocks such as schist and paragneiss, the foliation is commonly defined by the orientation of biotite crystals and biotite rich layers. Primary sedimentary features such as bedding were difficult to recognise due to significant metamorphism and recrystallisation.

In remotely sensed data, linear or curvilinear trends such as ridges, are interpreted as being representative of the $\mathrm{S} 1$ foliation. Quartzite units in particular, which are less common than in the Itremo sub-domain, are easy to recognise in remotely sensed data due to the large contrast in different Landsat bands (e.g. Supplementary D). In the Ikalamavony Domain the orientation of measured S1 foliations is dominantly northwest trending, and lineations and fold axes plunge moderately toward the west.

\subsubsection{D2 Deformation}

D2 deformation is most easily identifiable from remotely sensed data due to the large scale ( $>1 \mathrm{~km})$ wavelength folds. F2 antiforms and synforms are identifiable by the repetition of mapped geological units and constrained by structural measurements (Figure 4). D2 is defined by tight to isoclinal folds with axial traces approximately parallel to $\mathrm{S} 1$ in fold limbs. At the outcrop scale we observe these as decimetre- to metre-scale asymmetric, tight to isoclinal folds. F2 folds are similar-type folds, with thickened hinge zones and thinned limbs. An axial planar foliation is difficult to recognise in outcrops, but sometimes occurs as the alignment of biotite in hinge zones. Due to the isoclinal nature of folding, 
203 F2 axial traces are approximately parallel to S1 at the regional scale. F2 folds would have formed with 204 axial traces striking east-west, however due to subsequent deformation during D3 and D4, they are 205 now preserved with variable orientations.

\section{2.1.3. D3 Deformation and associated fold interference patterns}

207 We do not observe evidence for a third generation deformation event at the outcrop scale, however D3 208 folds are recognisable in remotely sensed data. The folding of F2 folds during D3 has produced a series 209 of fold interference patterns. Type 1 and type 2 fold interference patterns are observed in remotely 210 sensed data (Figure 4; Figure 5). Type 1 folds occur when an upright folding event is overprinted by an orthogonal upright folding event (Grasemann et al., 2004) and is expressed in Supplementary D(b). 212 Type 2 fold interference patterns occur when a recumbent folding event is orthogonally overprinted by 213 an upright folding event (Grasemann et al., 2004) and is expressed in Figure 5. We interpret D3 as the 214 result of $\sim$ northeast-southwest shortening (present day orientation). Cross-section Ik-Ik' (Figure 4) 215 has F2 folds that are very tight to isoclinal, with axial traces approximately parallel to F3 in F3 fold 216 limbs. This formed by $\sim$ southeast-directed recumbent folding that was overprinted by a north to 217 northwest trending F3 fold.

\section{2.1.4. D4 Deformation}

219 The axial traces of F3 folds vary across the Ikalamavony Domain, indicating a fourth generation of 220 deformation. For example the F3 fold axes vary from northwest-trending in the west near Miandrivazo 221 (e.g. Ik-Ik' cross-section in Figure 4), and curve to become north- to northeast-trending in the centre of 222 the map in Figure 4. We suggest this is caused by large wavelength ( $-30-50 \mathrm{~km})$, F4 open folding with 223 approximately east-west shortening. 

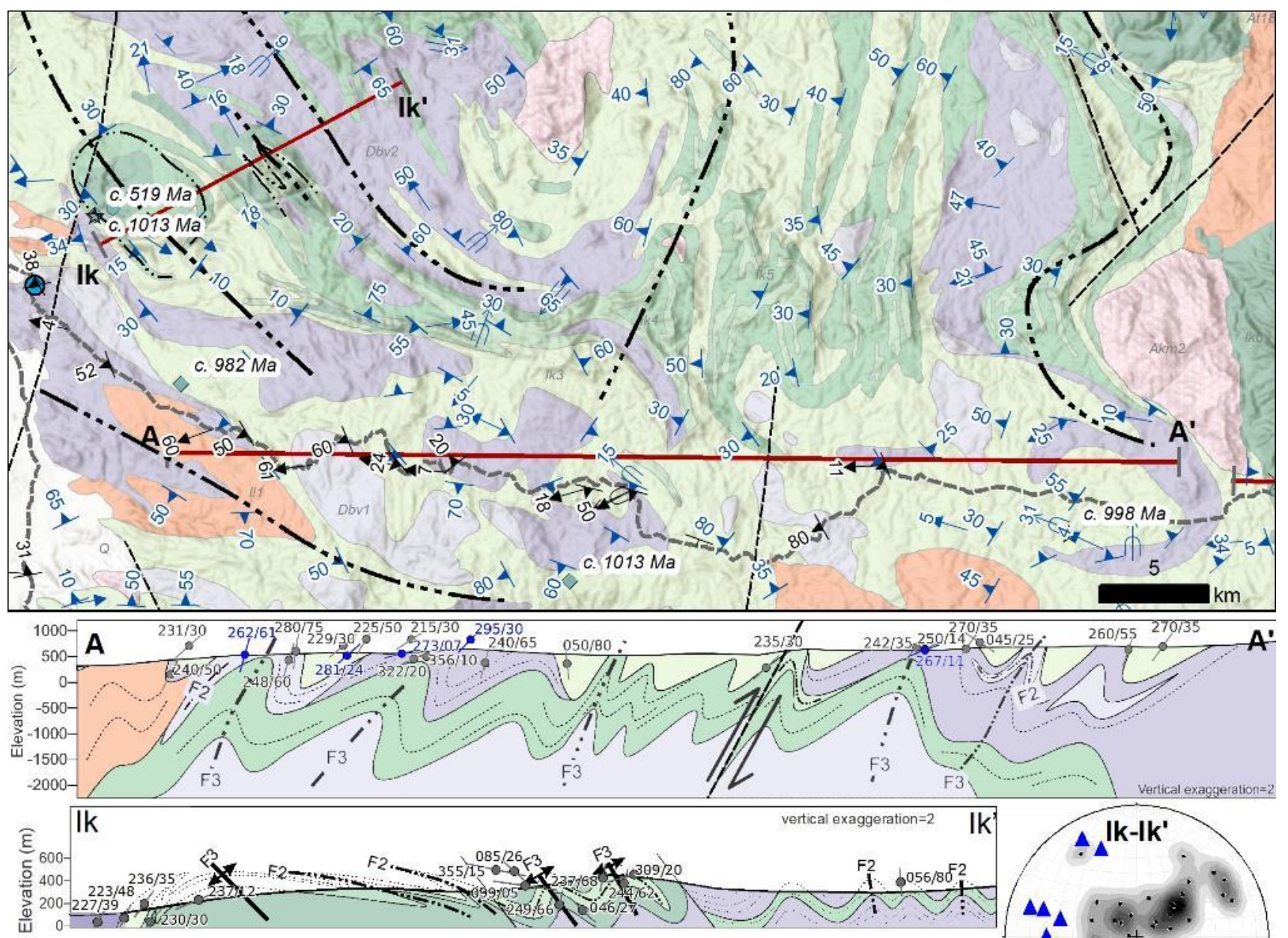

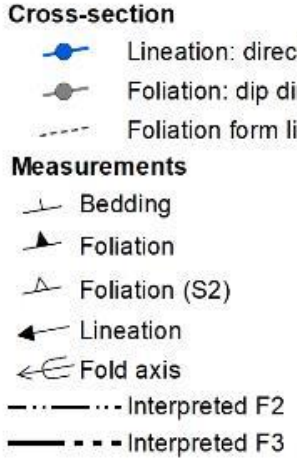

Cross-section $=-$ Road

gublished Geochron

is Metamorphic

$\checkmark$ Magmatic

- Detrital

Geological map 1:100,000

--- fault

Ambalavao Suite

Akm2: Granite, monzonite and syenite

Imorona-Itsindro Suite

II1: Imorona acid granite and

orthogneiss
Dabolava Suite

Dbv1: Dioritic and gabbroic

orthogneiss

Dbv2: Granitic and tonalitic orthogneiss

Ikalamavony Group

lk3: Quartzo-feldspathic paragneiss

Ik4: Calc-silicate marble and intercalated amphibolite

Ik5: Amphibolitic paragneiss

Ik6: Quartzite

Betsiboka Suite

At18: Granite and

orthogneiss

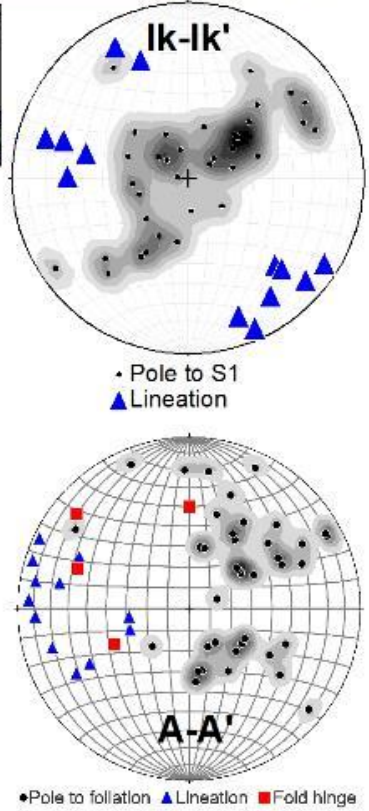

Figure 4 Geological map, structural data and cross-sections through the Ikalamavony Domain using both our new data (black) and previously published data (blue) (Macey et al., 2009). Fold axis measurements are generally interpreted to be F2 folds since we do not observe any overprinting fold generations in the field. A-A' shows the overall trend of structures in the Ikalamavony Domain. Ik-Ik': an example of type 2 fold interference patterns with north-west trending third generation upright folds. Sections generated using QProf plugin in QGIS. Structural measurements (dip direction/dip) within 2km of the section are projected along the profile. Topographic profile derived from 30 arc-second DEM of Africa (USGS). Geological polygons from Council for Geosciences 1:100000 mapsheets (Macey et al., 2010). 


\subsection{Itremo-Antananarivo Domain}

The Itremo Group is a continental marginal sequence deposited on basement rocks of the Antananarivo Domain (e.g. Cox et al., 1998; 2004). Therefore, we consider these 'domains' together. Transect B-B' (Figure 5) contains metasedimentary rocks of the Itremo Group, which are dominantly quartzites, marbles and schists, with minor conglomerates. The majority of quartzites that we observe are strongly recrystallised and it is often difficult to recognise primary sedimentary features. The Itremo-Antananarivo Domain was intruded by the c. 850-750 Ma Imorona-Itsindro Suite, after early deformation (Collins et al., 2003b). Together, these suites of rocks underwent a complex deformation history that must post-date the intrusion of the Imorona-Itsindro Suite.

Deformation intensity appears to weaken toward the east of the Itremo sub-domain, with an absence of complex fold interference patterns between Antsirabe and Antananarivo. The Imorona-Itsindro Suite in particular becomes progressively less deformed to the east. In the west, the Imorona-Itsindro Suite is folded into fold interference patterns, whereas in the east it only appears to be folded into weaklydefined F3 folds. This is consistent with our sampling of c. 850-750 Ma rocks along this weakly deformed margin (along the main road in Figure 2), where rock samples appear undeformed or very weakly deformed (documented in Table 1).

\subsubsection{D1 Deformation}

The orientation of $\mathrm{S} 1$ is variable in the Itremo sub-domain due to the abundance of poly-deformed folds. Similar to the Ikalamavony Domain, foliations strike dominantly north-northwest, with lineations and fold axes plunging moderately toward west-northwest. Like the Ikalamavony Domain, the first generation foliation at the outcrop scale is typically defined by the elongation and alignment of biotite, feldspar and quartz in orthogneisses and paragneisses (Figure 6a). In metasedimentary rocks such as quartzites and marbles, the foliation is sometimes defined by the orientation of biotite crystals and biotite rich layers, but is often difficult to recognise due to significant recrystallisation of quartz and a lack of other minerals. Primary sedimentary features such as bedding were difficult to recognise in quartzites due to significant recrystallisation. Within the quartzite packages, there are several conglomerate units with large (up to $\sim 5 \mathrm{~cm}$ ) pebbles (Figure 6b). Here we observe S0 as the interbedded pebble layers, and $\mathrm{S} 1$ as the flattening of pebbles. 

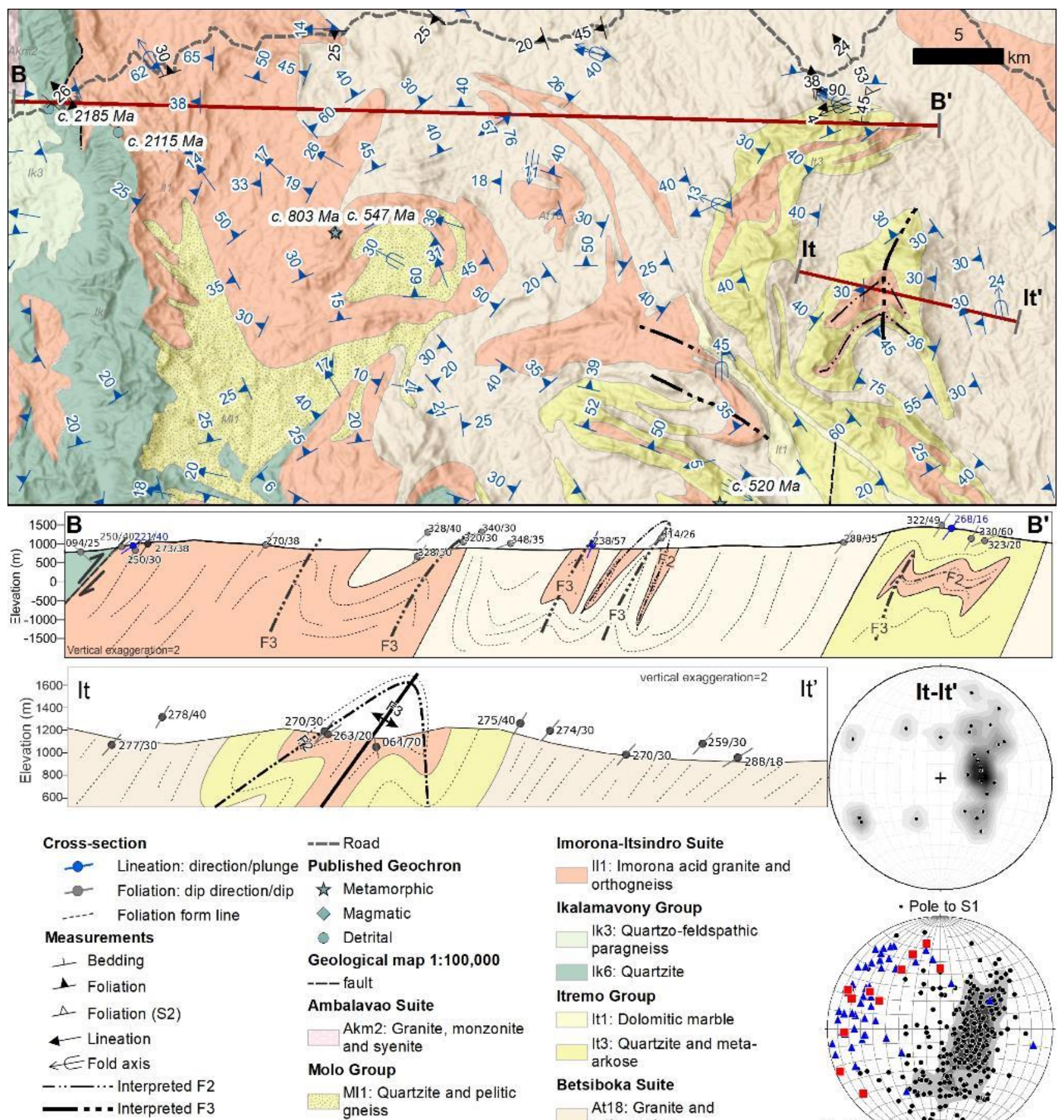

--Road

Published Geochron

is Metamorphic

$\diamond$ Magmatic

- Detrital

Geological map 1:100,000

-- - fault

Ambalavao Suite

Akm2: Granite, monzonite and syenite

Molo Group

Ml1: Quartzite and pelitic gneiss

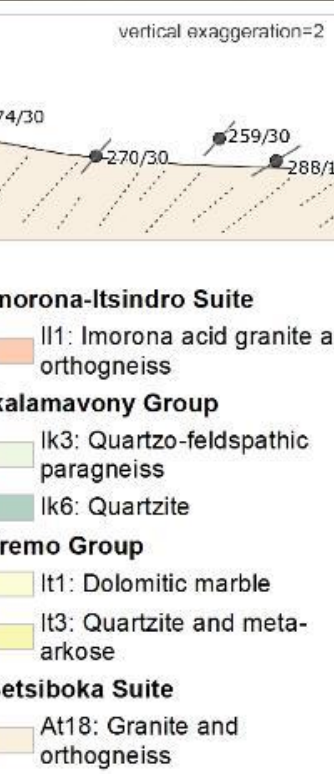

Figure 5 Geological map, structural data and cross-section through the Itremo-Antananarivo Domain using both our new data and previously published data (Macey et al., 2009). Measured fold axes are generally interpreted to be F2 folds since we do not observe any overprinting fold generations in the field. Similar to the Ikalamavony transect, the Itremo transect contains moderately to steeply west-dipping foliations, west-plunging lineations and west to northwest-plunging folds. It-It': an example of a type 2 fold interference pattern with D2 south-directed recumbent folding overprinted by a F3 north to north-east trending upright fold. Geological polygons from Council for Geosciences 1:100000 mapsheets (Macey et al., 2010). Sections generated using QProf plugin in QGIS. Structural measurements (dip direction/dip) within 2km of the section are projected along the profile. Topographic profile derived from 30 arc-second DEM of Africa (USGS). 
Identical to the Ikalamavony Domain, D2 is defined by tight to isoclinal folds with axial traces approximately parallel to $\mathrm{S} 1$ in fold limbs. At the outcrop scale we observe these as decimetre- to metre-scale asymmetric, tight to isoclinal folds (Figure 6c,d). F2 folds are similar-type folds, with thickened hinge zones and thinned limbs. F2 axial traces are approximately parallel to S1 at the regional scale. F2 folds are recognisable in remotely sensed data as $\sim 500-1000 \mathrm{~m}$ wavelength, tight to isoclinal folds (Figure 5). The original orientation of F2 folds would have had east-west striking axial traces, but have been subsequently deformed during D3 and D4. Further south where structures are more north-south trending, Tucker et al. (2007) interpreted east or south-east directed vergence from 278 these fold trends.

\subsubsection{D3 Deformation and associated fold interference patterns}

Similar to the Ikalamavony Domain, we do not observe evidence for a third generation deformation event at the outcrop scale, however D3 folds are recognisable in remotely sensed data. The majority of F3 fold axial traces are $\sim$ north-south striking, and orthogonally overprint F2 folds. We therefore interpret D3 as an east-west shortening event. The folding of F2 folds during D3 has produced a series of fold interference patterns. Type 2 fold interference patterns are observed in remotely sensed data in the Itremo sub-domain (Figure 5).

Adding to the complexity of the structure in It-It' is the juxtaposition of older units (the Archean Betsiboka Suite) structurally above younger units (Paleoproterozoic Itremo Group). Tucker et al. (2007) observed that the km-scale fold and thrust nappes (our interpreted D2), resulted in the inversion and repetition of Archean and Proterozoic rocks. This interpretation accounts for why the It-It' section contains older units that appear structurally above younger units.

\subsubsection{D4 Deformation}

The trend of structures vary from the northwest of central Madagascar near Miandrivazo, to the southeast of the study area along the eastern margin of the Itremo Group (Figure 2). Near Miandrivazo (e.g. Figure 4), F3 axial traces generally trend northwest-southeast. In the Itremo Group and further to the south, these structures are generally north-south trending. This trend broadly follows the curve of our structural style boundary between the western and eastern transects delineated in Figure 3. This regional variation may relate to D4 deformation or may relate to orogenic bending as orogenesis progressed. 

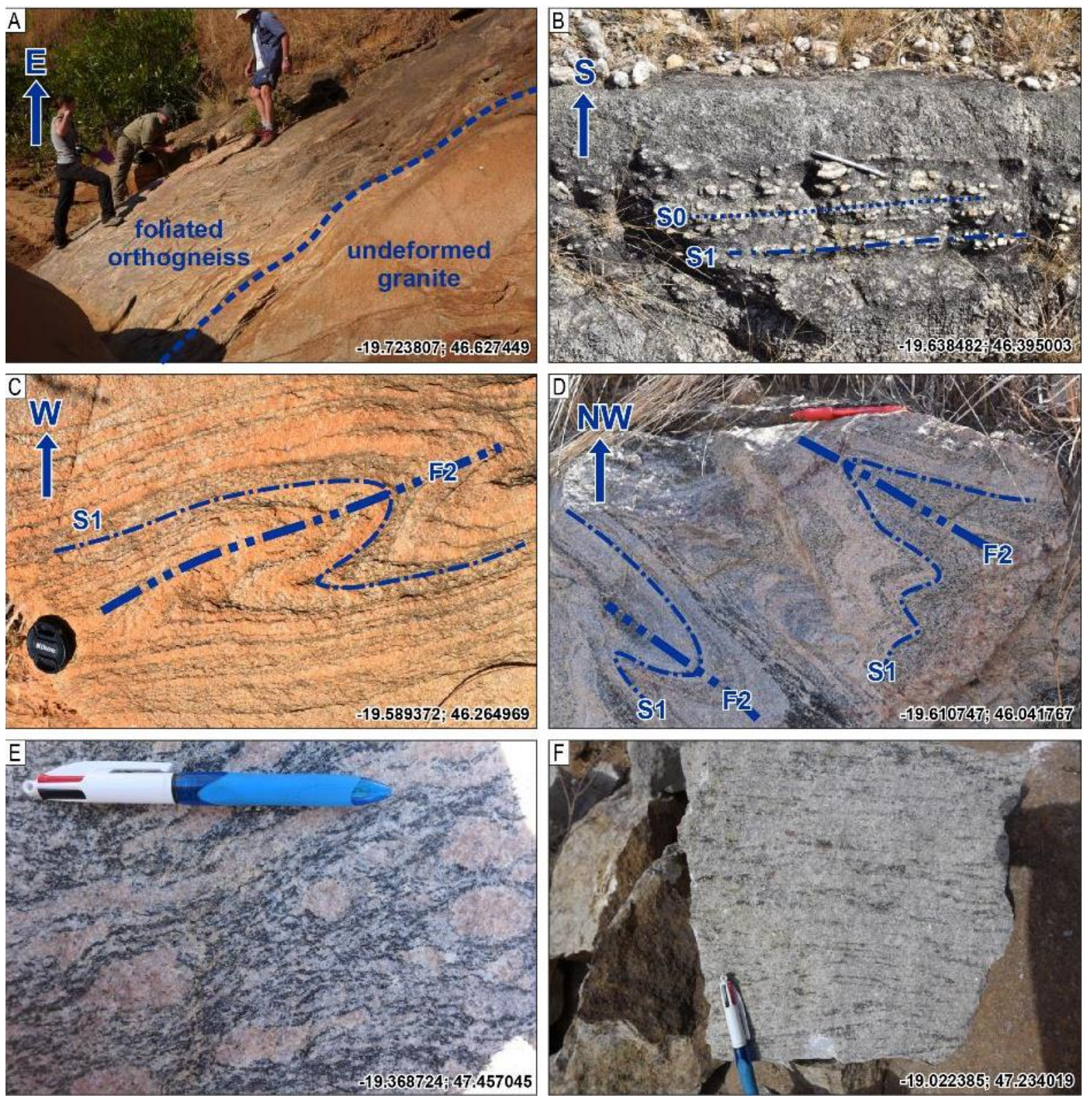

Figure 6 Examples of samples and field outcrops; latitude and longitude given in lower right corner and shown in Figure 2; a) outcrop of foliated gneiss (left) intruded by undeformed granite (right); b) flattened conglomerate where S1 is parallel to S0 in the Itremo Group of the Itremo sub-domain; c) S1 foliation folded around an F2 fold in the Itremo sub-domain; d) S1 foliation folding around F2 folds in the Itremo sub-domain; e) S1 foliation in a sample of augen gneiss of the Betsiboka Suite in the Antananarivo Domain; and f) S1 foliation in a sample of gneiss from the Antananarivo Domain, west of Antananarivo.

\subsection{Antananarivo Domain}

306 Precambrian outcrops between Antsirabe and Antananarivo are scarce due to the widespread coverage 307 of the Ankaratra Volcanics (Figure 2). Generally, deformation in this area is much less intense than the 308 Ikalamavony Domain and Itremo sub-domain, and we observe fewer deformation events (Figure 7). To 309 the east of the Antananarivo-Antsirabe road (Figure 2; Figure 7), there is a distinct change in structural 310 trend. In the Ikalamavony and Itremo domains, structures dominantly trend northwest. North of 311 Antananarivo, structures trend west (approximately the location of Antananarivo virgation zone in 312 Figure 2), and between Antananarivo and Antsirabe (Figure 7) structures trend $\sim$ north. This region was 
313 studied in detail in Collins et al. (2003a); Nédélec et al. (2000); Raharimahefa and Kusky (2006);

314 Raharimahefa and Kusky (2009); Raharimahefa et al. (2013). The intensity of these structures 315 increases toward the east, with at least four phases of deformation recognised resulting from the 316 Betsimisaraka Suture in eastern Madagascar.

\section{2.3.1. D1 Deformation}

318 Much like the western transect, at the outcrop scale we observe a pervasive foliation within the 319 Betsiboka Suite, which we interpret as an S1 foliation (Figure 6e,f). The foliation is commonly 320 preserved by the alignment of biotite, feldspar and quartz in orthogneisses. Structural measurements 321 indicate that S1 foliations between Antsirabe and Antananarivo dominantly strike $\sim$ north-northeast, 322 with dips moderately to the west (Figure 7). North of Antananarivo, S1 is more variable, and folded 323 following the Antananarivo virgation zone (e.g. Nédélec et al., 2000). We observe a well-defined 324 gneissic foliation within the Archean Betsiboka Suite, which may have originally formed prior to 325 Neoproterozoic deformation. If this is the case, then subsequent Neoproterozoic deformation was 326 approximately the same orientation, as we do not observe cross-cutting fabrics.

\subsubsection{D2 Deformation}

328 We do not observe D2 structures at the outcrop scale in this section. However, the repetition of 329 mapped Ambatolampy Group within the Betsiboka Suite (Figure 7), indicates that the two elongated 330 Ambatolampy Group bodies in Figure 7 represent tight to isoclinal F2 folds. 

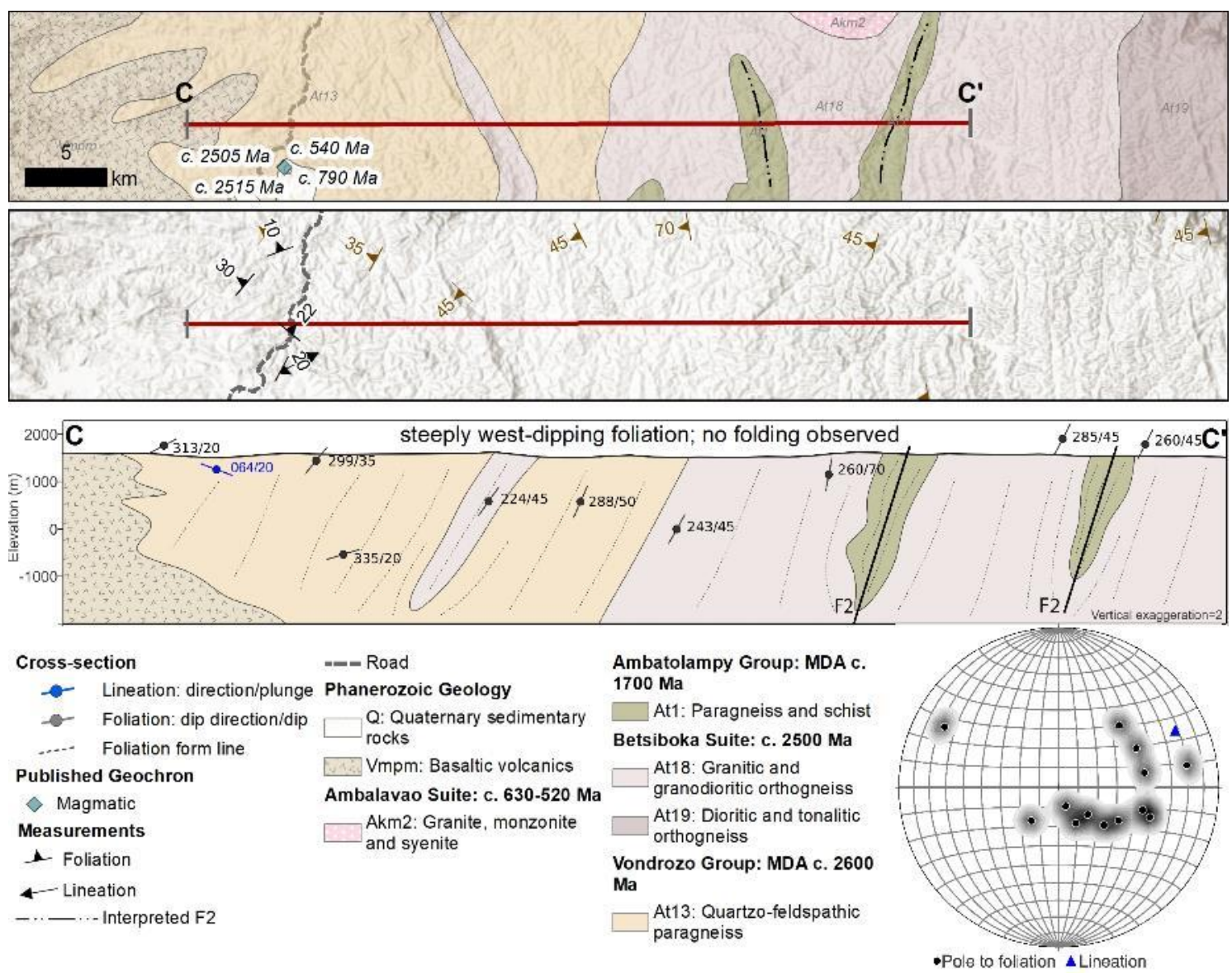

Figure 7 Geological map, structural data and cross-section through the Antananarivo Domain. This transect does not contain the complex folding that we observe in the Ikalamavony and Itremo domains. Here, foliations are steeply westdipping. Geological polygons from Roig et al. (2012). Sections generated using QProf plugin in QGIS. Structural measurements (dip direction/dip) within $\sim 2 \mathrm{~km}$ of the section are projected along the profile. Topographic profile derived from 30 arc-second DEM of Africa (USGS).

\section{Thermochronology}

A range of magmatic and orthogneiss samples were collected with the aim of having a representative sample set of the major magmatic suites of central Madagascar. This is important for determining overprinting relationships of key structural events, and determining relative and absolute timing constraints on these events. We used four geochronology/thermochronology techniques: zircon $\mathrm{U}-\mathrm{Pb}$ (closure temperature $\sim 900-1000^{\circ} \mathrm{C}$ ), apatite $\mathrm{U}-\mathrm{Pb}$ (closure temperature $\sim 350-550^{\circ} \mathrm{C}$ ), muscovite $\mathrm{Rb}-$ $\mathrm{Sr}$ (closure temperature $\sim 500-600^{\circ} \mathrm{C}$ ) and biotite $\mathrm{Rb}-\mathrm{Sr}$ (closure temperature $\sim 300-400^{\circ} \mathrm{C}$ ). The results are summarised in Figure 8 and documented more extensively in Supplementary B. Detailed methodologies for these techniques are also provided in Supplementary B. $\mathrm{Rb}-\mathrm{Sr}$ mica dating using LA-QQQ-ICP-MS is a novel technique, and this data presents some of the first published data of its kind. The good agreement of $\mathrm{Rb}-\mathrm{Sr}$ mica ages with $\mathrm{U}-\mathrm{Pb}$ apatite ages, which have similar closure temperatures, demonstrates that $\mathrm{Rb}-\mathrm{Sr}$ mica dating is a useful tool for dating medium-temperature events. Due to the abundance of samples (41 in total), detailed results for each sample and outcrop, including plots of isotopic data, are provided in Supplementary B. Sample descriptions, location and age data are summarised in Table 1. Isotopic data are given in Supplementary C. 
Table 1 Summary of sample descriptions, outcrop and cross-cutting relationships, and age data. Letters given for each outcrop are the interpreted order of formation/intrusion, based on cross-cutting relationships. All zircon ages are interpreted as magmatic crystallisation ages except for metamorphic ages indicated by $\left({ }^{*}\right)$ and lower intercept ages indicated by $(\#)$.

\begin{tabular}{|c|c|c|c|c|c|c|c|c|c|c|c|}
\hline $\begin{array}{l}\text { Sample } \\
\text { ID }\end{array}$ & $\begin{array}{l}\text { Trans } \\
\text { ect }\end{array}$ & $\begin{array}{l}\text { Outcr } \\
\text { op }\end{array}$ & $\begin{array}{l}\text { Sample } \\
\text { description }\end{array}$ & $\begin{array}{l}\text { Magmatic } \\
\text { Suite }\end{array}$ & Latitude & Longitude & $\begin{array}{l}\text { Elevat } \\
\text { ion } \\
(\mathrm{m})\end{array}$ & $\begin{array}{l}\text { Zircon } \\
\text { U-Pb age } \\
(\mathrm{Ma})\end{array}$ & $\begin{array}{l}\text { Apatite } \\
\text { U-Pb age } \\
(\mathrm{Ma})\end{array}$ & $\begin{array}{l}\text { Muscovite } \\
\text { Rb-Sr age } \\
(\mathrm{Ma})\end{array}$ & $\begin{array}{l}\text { Biotite } \\
\text { Rb-Sr age } \\
(\mathrm{Ma})\end{array}$ \\
\hline M16-24 & West & 1 & $\begin{array}{l}\text { Undeformed K- } \\
\text { feldspar rich } \\
\text { granite. Intrudes } \\
\text { deformed } \\
\text { gabbro } \\
\text { interpreted as } \\
\text { the Dabolava } \\
\text { Suite }\end{array}$ & Ambalavao & -19.5443 & 45.47028 & 182 & $576 \pm 24$ & - & $519 \pm 69$ & $505 \pm 59$ \\
\hline M16-32 & West & $2 / \mathrm{A}$ & $\begin{array}{l}\text { Coarse-grained } \\
\text { gneiss with 1-2 } \\
\text { cm biotite } \\
\text { phenocrysts }\end{array}$ & Betsiboka & -19.6107 & 46.53399 & 989 & $2553 \pm 24$ & $519 \pm 11$ & $446 \pm 161$ & $502 \pm 20$ \\
\hline M16-33 & West & $2 / D$ & $\begin{array}{l}\text { Undeformed } \\
\text { fine-grained } \\
\text { granodioritic } \\
\text { dyke, intrudes } \\
\text { M16-32 }\end{array}$ & $\begin{array}{l}\text { Imorona- } \\
\text { Itsindro }\end{array}$ & -19.6107 & 46.53399 & 989 & $798 \pm 24$ & - & - & - \\
\hline M16-34 & West & $2 / \mathrm{C}$ & $\begin{array}{l}\text { Thin dyke } \\
\text { intruding M16- } \\
32\end{array}$ & Betsiboka & -19.6107 & 46.53399 & 989 & $2511 \pm 14$ & $515 \pm 7$ & - & - \\
\hline M16-35 & West & $2 / \mathrm{B}$ & $\begin{array}{l}\text { K-feldspar rich } \\
\text { deformed dyke }\end{array}$ & Betsiboka & -19.6107 & 46.53399 & 989 & $\begin{array}{l}2583 \pm 26 \\
2494 \pm 14 \\
(*)\end{array}$ & $502 \pm 6$ & - & $513 \pm 18$ \\
\hline M16-15 & West & $3 / \mathrm{A}$ & $\begin{array}{l}\text { K-feldspar and } \\
\text { biotite rich, } \\
\text { foliated } \\
\text { orthogneiss }\end{array}$ & Betsiboka & -19.7239 & 46.62736 & 1067 & $2456 \pm 17$ & $492 \pm 5$ & $624 \pm 152$ & $528 \pm 18$ \\
\hline M16-16 & West & $3 / B$ & $\begin{array}{l}\text { Undeformed } \\
\text { granite, } \\
\text { occasionally } \\
\text { very weakly } \\
\text { foliated }\end{array}$ & $\begin{array}{l}\text { Imorona- } \\
\text { Itsindro }\end{array}$ & -19.7239 & 46.62736 & 1067 & $795 \pm 24$ & $498 \pm 7$ & $506 \pm 82$ & $499 \pm 68$ \\
\hline M16-17 & West & $3 / C$ & $\begin{array}{l}\text { Pegmatite } \\
\text { veins, k-spar } \\
\text { rich }\end{array}$ & $\begin{array}{l}\text { Imorona- } \\
\text { Itsindro }\end{array}$ & -19.7239 & 46.62736 & 1067 & c. 795 & $494 \pm 7$ & $526 \pm 39$ & $492 \pm 51$ \\
\hline M16-46 & East & 4/A & $\begin{array}{l}\text { Foliated } \\
\text { orthogneiss, } \\
\text { medium- } \\
\text { grained, K- } \\
\text { felsdpar and } \\
\text { biotite rich }\end{array}$ & Betsiboka & -19.1599 & 47.51211 & 1351 & $\begin{array}{l}2522 \pm 8 \\
543 \pm 27 \\
(\#)\end{array}$ & $497 \pm 15$ & $604 \pm 211$ & $512 \pm 24$ \\
\hline M16-47 & East & 4/B & $\begin{array}{l}\text { Undeformed } \\
\text { cross-cutting } \\
\text { granite }\end{array}$ & $\begin{array}{l}\text { Imorona- } \\
\text { Itsindro }\end{array}$ & -19.1599 & 47.51211 & 1351 & $\begin{array}{l}798 \pm 48 \\
532 \pm 44 \\
(\#)\end{array}$ & - & $657 \pm 98$ & - \\
\hline M16-45 & East & 5 & $\begin{array}{l}\text { Medium- } \\
\text { grained granite, } \\
\text { undeformed }\end{array}$ & Ambalavao & -19.0869 & 47.54429 & 1312 & $543 \pm 18$ & $507 \pm 35$ & - & $512 \pm 16$ \\
\hline M16-52 & East & $6 / \mathrm{A}$ & $\begin{array}{l}\text { Granite, very } \\
\text { weakly foliated }\end{array}$ & Ambalavao & -18.589 & 47.23721 & 1359 & $568 \pm 16$ & $484 \pm 14$ & $527 \pm 51$ & $511 \pm 16$ \\
\hline M16-53 & East & $6 / B$ & $\begin{array}{l}\text { Cross-cutting K- } \\
\text { feldspar rich } \\
\text { granite }\end{array}$ & Ambalavao & -18.589 & 47.23721 & 1359 & C. 568 & $500 \pm 10$ & $537 \pm 35$ & $521 \pm 18$ \\
\hline
\end{tabular}




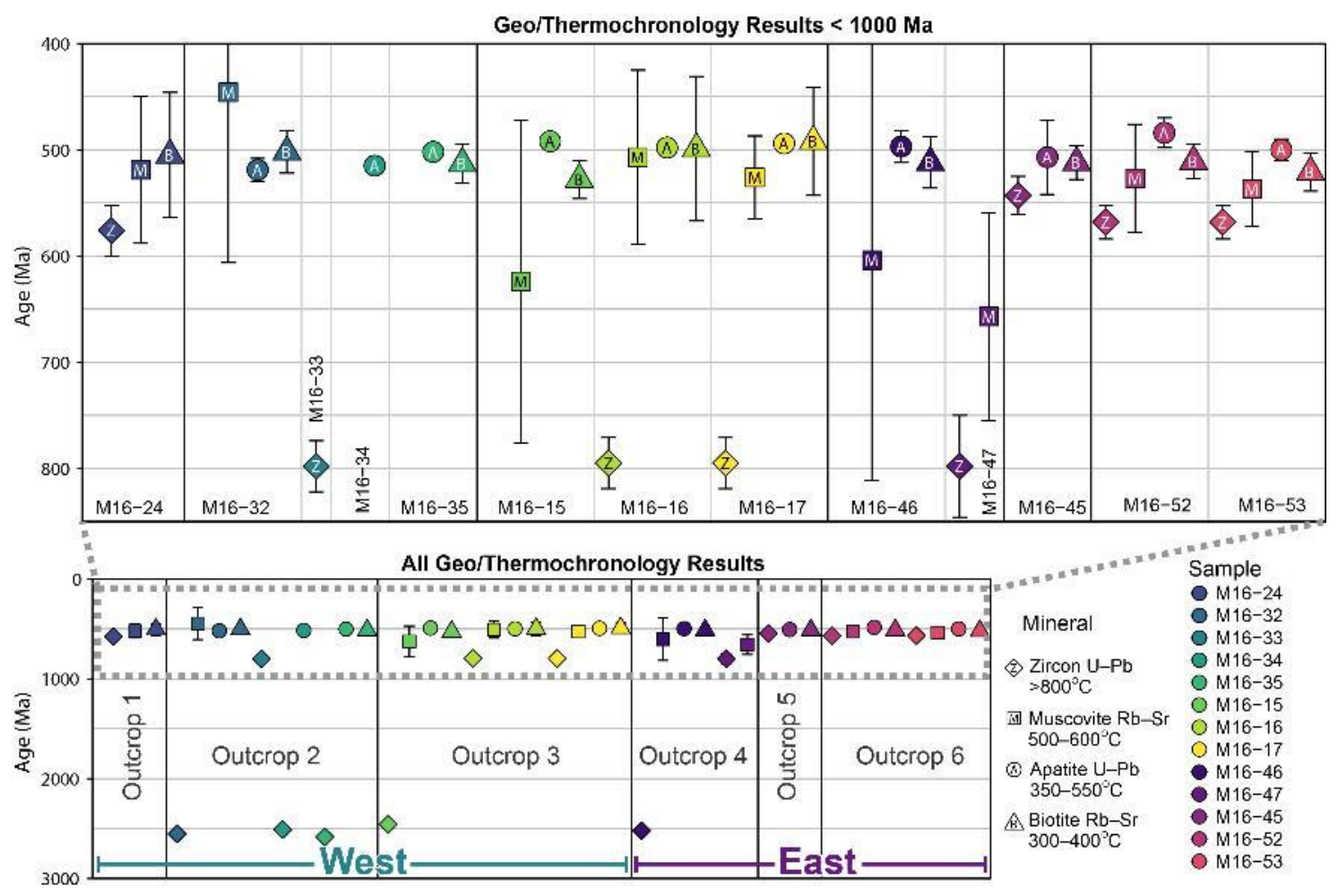

Figure 8 Summary of geo/thermochronology data for each sample and outcrop collected in this study. Error bars are $2 \sigma$. Sample locations shown in Figure 2. The bottom figure shows all of the sample data collected, and the top image zooms in on all data that are younger than $1000 \mathrm{Ma}$. Plots of isotopic data associated with these calculated ages are presented in Supplementary B.

\section{Discussion}

\subsection{Structural evolution of central Madagascar}

The structural style of the Ikalamavony and Itremo domains are indistinguishable and we suggest that D1-D3 (and possibly D4) in both domains were the result of the same orogenic system. Type 1 and type 2 fold interference patterns are common in fold-and-thrust belts, and more commonly form during progressive deformation rather than discrete deformation events. A myriad of complex processes ranging from rheological contrasts to progressive rotation during deformation, commonly cause fold structures with trends that are oblique to the transport direction of the overall fold-andthrust belt (e.g. Poblet and Lisle, 2011). Therefore, we suggest that D1-D3 in the Ikalamavony Domain and Itremo sub-domain formed during the same orogenic event, through progressive deformation, consistent with the interpretation based on metamorphism in this region by Moine et al. (2014).

A structure with very similar geometry and orientation to the type 2 interference pattern highlighted in Figure 5, was modelled by Armistead et al. (2018). They showed that this type of feature formed from south-directed, tight, recumbent folding that was orthogonally overprinted by third generation upright folding. In our example from the Itremo Group, the F2 recumbent folding formed during south to slightly south-west directed folding that locally formed by north-south shortening. The overprinting F3 upright fold formed during east-west shortening that resulted in a north to north-east trending 
379 axial trace. These interpreted kinematics are consistent with previous interpretations for deformation 380 in the Itremo Group (Collins et al., 2003b; Tucker et al., 2007).

381 As pointed out in Tucker et al. (2007), nappes in the southern Itremo Domain are east-verging and 382 were likely produced within a zone of west-dipping subduction (present day direction). We interpret 383 structures in our study areas of the Ikalamavony and Itremo domains to be dominantly north-west 384 trending, with northeast directed vergence, developed as a result of $\sim$ northeast-southwest shortening 385 (present day orientation). We propose that continental collision southwest of the Ikalamavony Domain 386 and Itremo sub-domain was responsible for deformation in central Madagascar. Subduction prior to 387 continental collision was $\sim$ southwest dipping.

388 Tucker et al. (2007) proposed that complex folds in the Itremo sub-domain can be broadly considered 389 in two groups; "high-grade, internal nappes" and "low-grade, external nappes." These were considered 390 to be separated by a west-dipping thrust fault, although the exact location of this boundary is 391 ambiguous from the highly schematic diagrams presented in that study. We broadly agree that 392 metamorphic grade and deformation intensity appears to increase toward the west, however a sharp 393 tectonic boundary hasn't been observed in this study within the Itremo Group. We do however see a 394 major tectonic boundary between the Ikalamavony Domain and the Itremo-Antananarivo Domain. 395 This boundary may more accurately reflect the boundary between the internal and external nappes 396 proposed by Tucker et al. (2007).

397 The weakly defined, open folding associated with D4 may have occurred in the late stages of folding 398 and thrusting of the Itremo sub-domain and Ikalamavony Domain, or may be related to far-field 399 deformation associated with orogenesis in eastern Madagascar (Collins et al., 2003a).

400 In the eastern part of the study area, east of the 'structural style boundary' in Figure 2 and Figure 3, the 401 deformation style changes in orientation and intensity. Transect $C-C$ ' is less deformed than the 402 Ikalamavony and Itremo transects (Figure 9), and we do not observe any complex fold interference 403 patterns here. The orientation of structures also change, and become more north to north-east 404 trending. Further east of our C-C' transect is the dextral Angavo Shear Zone, which was active at $550 \pm$ $4054 \mathrm{Ma}$ (Raharimahefa and Kusky, 2010). Collins et al. (2003a) constructed a cross-section from 406 Antananarivo eastwards to Brickaville along the east coast of Madagascar (Figure 9). This transect 407 region contains a deformation sequence distinct from the Ikalamavony and Itremo domains and was 408 therefore caused by a different tectonic event. Although controversial, there is significant metamorphic 409 and structural evidence that the sequence of deformation described by Collins et al. (2003a) can be 410 attributed to the c. 550 Ma Betsimisaraka Suture that amalgamated Madagascar with the Dharwar 411 Craton of India. 


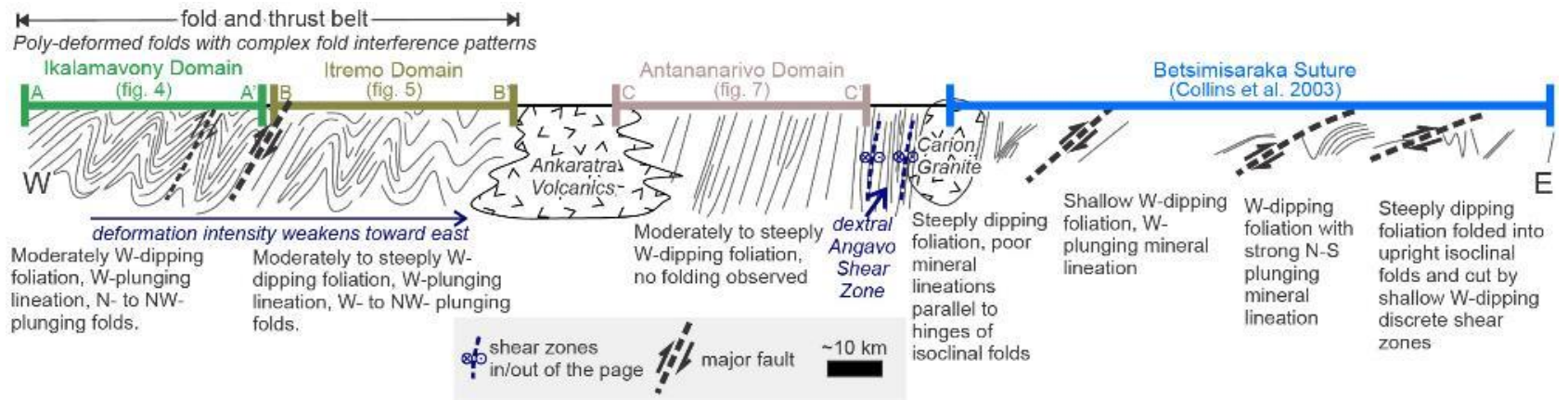

Figure 9 Schematic cross-section through central Madagascar from Miandrivazo to Brickaville, combining the cross-sections of Figure 4, Figure 5, Figure 7 and that of Collins et al. (2003a). The Ikalamavony and Itremo domains preserve the same structural styles and kinematics. A change in structural style occurs east of these sections, with the Antananarivo Domain section containing no complex fold interference patterns. Further east, Collins et al. (2003a) interpret intense deformation associated with the Neoproterozoic-Cambrian Betsimisaraka Suture.

\subsection{Temporal constraints on deformation}

\subsubsection{Relative timing of deformation}

Understanding the ages of geological units that are deformed and undeformed can help constrain the timing of deformation. At the regional scale in the western transect, the c. 850-750 Ma ImoronaItsindro Suite is poly-deformed, and therefore was intruded prior to the onset of at least D2 and D3. In the eastern transect and in the region studied by Collins et al. (2003a); Nédélec et al. (2000); Raharimahefa and Kusky (2006); Raharimahefa and Kusky (2009), the Imorona-Itsindro Suite is not poly-deformed into complex fold interference patterns but instead is elongated along the length of the c. 550 Ma Angavo shear zone (Figure 1b; Figure 9). This indicates that different structural regimes are responsible for deformation in the west and east of Madagascar.

In the Ikalamavony Domain and Itremo sub-domain, the c. 550 Ma Ambalavao Suite is undeformed and, therefore, provides a minimum age constraint on deformation here. In the east, the Ambalavao Suite is represented by both deformed and undeformed rocks. We therefore suggest that deformation in the Ikalamavony Domain and Itremo sub-domain occurred between c. 750 and c. 550 Ma, which is consistent with interpretations by Tucker et al. (2007). Deformation in eastern Madagascar likely occurred later at c. $550 \mathrm{Ma}$, which is consistent with age determinations for the Angavo Shear Zone and Antananarivo virgation zone (Meert et al., 2003; Nédélec et al., 2000; Paquette and Nédélec, 1998; Raharimahefa and Kusky, 2010).

\subsubsection{Thermochronology}

We have used minerals that record a range of temperatures in an attempt to capture different stages of the tectonic evolution of Madagascar. Our sampling included the major magmatic suites of Madagascar, including the c. 2500 Ma Betsiboka Suite, the c. 850-750 Ma Imorona-Itsindro Suite, and the c. $550 \mathrm{Ma}$ Ambalavao Suite (Figure 8). Interestingly, apatite U-Pb ages-which record the age the minerals were cooled through $\sim 350-550^{\circ} \mathrm{C}$ (Chamberlain and Bowring, 2001; Schoene and Bowring, 2007) —are all within a narrow age range from $519 \pm 11$ Ma to $484 \pm 14 \mathrm{Ma}$, regardless of their magmatic crystallisation age. Muscovite and biotite, which have $\mathrm{Rb}-\mathrm{Sr}$ closure temperatures of 500- 
$600^{\circ} \mathrm{C}$ (Armstrong et al., 1966) and $\sim 300-400^{\circ} \mathrm{C}$ (Del Moro et al., 1982; Jenkin et al., 2001; Verschure et al., 1980), respectively, also record ages within a narrow range between $657 \pm 98 \mathrm{Ma}$ and $446 \pm 161$ Ma for muscovite (albeit, large uncertainties) and between $528 \pm 18 \mathrm{Ma}$ and $492 \pm 51$ Ma for biotite. This implies that the final stages of orogenesis in Madagascar, regardless of whether this was in the west or east, affected the entire central region of the island, where rocks were either reset to at least $\sim 500^{\circ} \mathrm{C}$ or cooled through $\sim 500^{\circ} \mathrm{C}$ at c. $500 \mathrm{Ma}$.

Multiple thermochronometers have provided insights into the medium-temperature thermo-tectonic evolution across the western and eastern part of Madagascar. As we have shown here, the more recent c. 520-480 Ma thermo-tectonic event affected the entire island such that it cooled synchronously through $\sim 500-300^{\circ} \mathrm{C}$ at c. $500 \mathrm{Ma}$. The c. 520-480 Ma regional thermal perturbation would have overprinted prior events, obscuring any evidence of a pre-existing thermo-tectonic evolution. Using thermochronometers that record temperatures higher than $\sim 600^{\circ} \mathrm{C}$ (e.g. monazite $\mathrm{U}-\mathrm{Pb}$ ) in future research may be able to provide further constraints on the timing of orogenesis - particularly in regions distal from the collision zone and in rocks that are not in contact with the Ambalavao Suite where temperatures during the c. $550 \mathrm{Ma}$ event may not have been hot enough to cause complete reset. Without direct dating of the structures observed, we need to look further afield for evidence of subduction and collision that resulted in deformation of central Madagascar.

\subsection{Tectonic model for the evolution of central Madagascar}

The boundaries between the major domains in southern Madagascar represent possible suture zones responsible for deformation in the Ikalamavony Domain and Itremo sub-domain. Prior to the juxtaposition of the Itremo sub-domain and Ikalamavony Domain, we agree with previous interpretations that the Itremo Group was deposited on the Antananarivo Domain basement (Figure 10a) (Cox et al., 1998; 2004) and that the Ikalamavony Domain evolved as an exotic island arc terrane (Figure 10b) (Archibald et al., 2017a). The presence of the Imorona-Itsindro Suite in the Ikalamavony Domain indicates that it must have accreted to central Madagascar before c. $850 \mathrm{Ma}$ (Figure 10c). A large west-dipping thrust fault separating the Ikalamavony Domain from the Itremo sub-domain (Figure 5; Figure 9), possibly represents this suture zone (schematic thrust in Figure 10c). This implies west-dipping subduction, which is consistent with previous models for the accretion of the Ikalamavony Domain to central Madagascar (e.g. Boger et al., 2019).

Based on the interpreted kinematics and overprinting relationships, deformation of the Ikalamavony Domain and Itremo sub-domain was the result of continental collision. Increasing deformation intensity in the Ikalamavony Domain and the orientation of structures imply that the collision zone must have lain southwest of these domains.

Boger et al. (2014); (2019) suggested that the Beraketa high strain zone that separates the Anosyen and Androyen domains represents a c. 580-520 Ma suture. This interpretation was based on c. 630-600 Ma metamorphism restricted to the west of this high-strain zone, and widespread c. 580-520 Ma magmatism and metamorphism on both sides of the high-strain zone. In this model, the subduction zone was east-dipping (present day direction), and resulted in the syn- to post-tectonic Ambalavao granites throughout Madagascar (Figure 10). However, the structures we have described and those 
483 described by Tucker et al. (2007) require a west-dipping (top to the east; present day direction) sense 484 of movement, making an east-dipping subduction zone beneath the Antananarivo Craton at this time 485 unlikely.

486 These authors interpreted that another west-dipping subduction zone was active beneath the Vohibory 487 Domain until c. $650 \mathrm{Ma}$ (Figure 10e), and that collision between the Vohibory Domain and Androyen 488 Domain occurred at c. 630-610 Ma (Figure 10f), outboard from the Antananarivo Craton (marked by 489 the Ampanihy high-strain zone/Vohibory Suture in Figure 1b). In this model, subduction was west490 dipping (Figure 10e,f). Horton et al. (2016) also interpreted that the Androyen and Anosyen domains 491 collided with the Vohibory Domain at c. $630 \mathrm{Ma}$, based on monazite and zircon geochronology. In our 492 view, this collision zone is most consistent with evidence we see from a structural perspective. We 493 therefore propose that the Vohibory suture was responsible for high intensity deformation and 494 polydeformed folds in the Ikalamavony and Itremo domains. It's likely that deformation associated 495 with this event is present in the Androyen and Anosyen domains, however structures are much more 496 steeply dipping and more highly strained here, meaning that recognition of distinct folding events is 497 difficult (Figure 10e). As interpreted by Boger et al. (2014); Boger et al. (2019), the Vohibory Suture 498 would have been west-dipping (present day direction), resulting in the emplacement of the c. $630 \mathrm{Ma}$ 499 Marasavoa Suite in the Vohibory Domain. Metamorphism of this age is also recorded in the Androyen 500 Domain.

501 A change in deformation style and kinematics toward the east of Madagascar and younger 502 geochronological constraints, indicate that complex folding in eastern Madagascar formed in response 503 to a different event than that in the west (Figure 10g). Although we did not look at this region in great 504 detail, the changes across central Madagascar from west to east, combined with extensive structural 505 studies published on eastern Madagascar (Collins et al., 2003a; Martelat et al., 2000; Nédélec et al., 506 2000; Raharimahefa and Kusky, 2006; Raharimahefa and Kusky, 2009; Raharimahefa et al., 2013), 507 indicate that a west-dipping subduction zone was active at c. $550 \mathrm{Ma}$, somewhere in the region of the 508 Betsimisaraka Suture. 


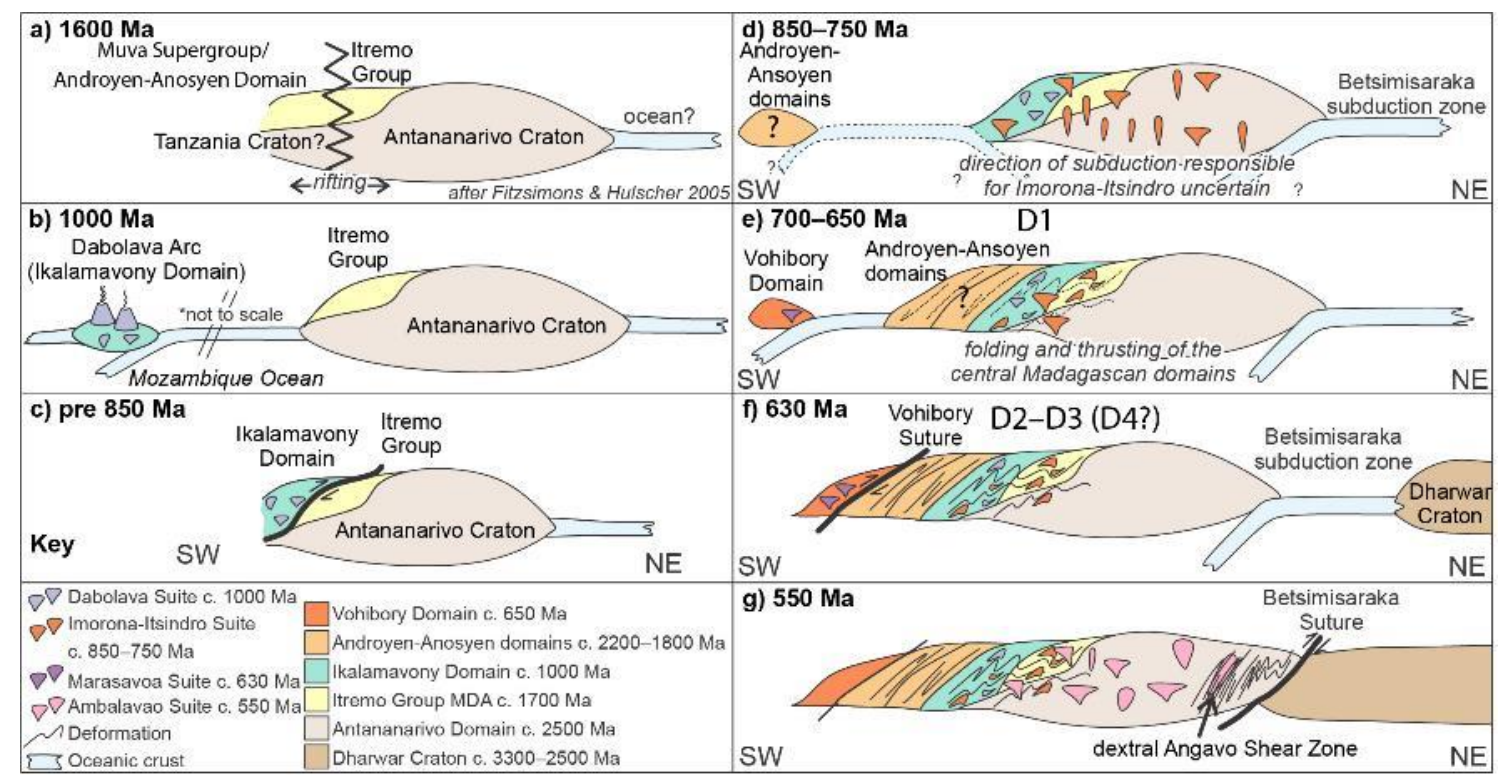

510 Figure 10 Schematic diagram showing our interpretation of the evolution of central Madagascar. a) Sometime after the

deposition of the Itremo Group/Muva Supergroup onto the Antananarivo Craton/Tanzania Craton, these regions begin to rift (Cox et al., 2004; Fitzsimons and Hulscher, 2005); b) at c. 1000 Ma the Dabolava Arc forms as an oceanic island arc outboard from the Antananarivo Domain (Archibald et al., 2017a); c) prior to the intrusion of the c. 850-750 Ma ImoronaItsindro Suite, the Ikalamavony Domain is thrust over the Antananarivo/Itremo Domain; d) the intrusion of the ImoronaItsindro Suite resulting from Andean-type subduction, with polarity uncertain (Archibald et al., 2017b); e) west-dipping subduction beneath the Vohibory Domain, with the beginning of deformation (D1); f) closure of the Mozambique ocean along the Vohibory Suture resulting in complex deformation that we have interpreted in central Madagascar (D2-D3) and

\section{Conclusions}

We have integrated remote sensing, field data and thermochronology to unravel complex deformation in the Ikalamavony and Itremo domains of central Madagascar. We have recognised four generations (D1-D4) of deformation that resulted in complex fold interference patterns in the Ikalamavony and Itremo domains of central Madagascar. We interpret deformation here as the result of c. $630 \mathrm{Ma}$ collision of Azania with Africa along the Vohibory Suture in southwestern Madagascar. In eastern Madagascar, deformation is syn- to post- $550 \mathrm{Ma}$, which likely formed in response to the final closure of the Mozambique Ocean along the Betsimisaraka Suture that amalgamated Madagascar with the Dharwar Craton of India. Apatite U-Pb and novel LA-QQQ-ICP-MS muscovite and biotite $\mathrm{Rb}-\mathrm{Sr}$ thermochronology indicate that much of central Madagascar cooled through $\sim 500^{\circ} \mathrm{C}$ at c. $500 \mathrm{Ma}$. We have shown the importance of using medium-temperature thermochronometers to date the cooling stages after orogenesis, and the potential for $\mathrm{Rb}-\mathrm{Sr}$ mica dating to provide useful thermochronological constraints.

\section{Acknowledgments}

EarthArXiv is thanked for hosting a preprint version of this manuscript, earlier versions of this manuscript can be found there at doi.org/10.31223/osf.io/x46vc. We would like to thank Paul Macey, from the Council for Geoscience, South Africa, for providing additional structural data. Renée Tamblyn 
is thanked for helpful discussions about $\mathrm{Rb}-\mathrm{Sr}$ data. We thank Benjamin Emmel, the editor Deta Gasser and two anonymous reviewers for their helpful feedback. This manuscript was also reviewed as part of SA's PhD thesis by Kathryn Goodenough and Peter Johnson, their valuable feedback greatly improved this manuscript. SA was funded by an Australian government $\mathrm{PhD}$ Scholarship and AC is funded by an Australian Research Council Future Fellowship FT120100340. This is a contribution to IGCP projects 628 (Gondwana Map) and 648 (Supercontinent Cycles and Global Geodynamics).

\section{References}

Archibald, D.B., Collins, A.S., Foden, J.D., Payne, J.L., Macey, P.H., Holden, P. and Razakamanana, T., 2017a. Stenian-Tonian arc magmatism in west-central Madagascar: the genesis of the Dabolava Suite. Journal of the Geological Society: jgs2017-028.

Archibald, D.B., Collins, A.S., Foden, J.D., Payne, J.L., Taylor, R., Holden, P., Razakamanana, T. and Clark, C., 2015. Towards unravelling the Mozambique Ocean conundrum using a triumvirate of zircon isotopic proxies on the Ambatolampy Group, central Madagascar. Tectonophysics, 662: 167-182.

Archibald, D.B., Collins, A.S., Foden, J.D. and Razakamanana, T., 2017b. Tonian Arc Magmatism in Central Madagascar: The Petrogenesis of the Imorona-Itsindro Suite. The Journal of Geology, 125(3): ooo-ooo.

Armistead, S.E., Betts, P.G., Ailleres, L., Armit, R.J. and Williams, H.A., 2018. Cu-Au mineralisation in the Curnamona Province, South Australia: A hybrid stratiform genetic model for Mesoproterozoic IOCG systems in Australia. Ore Geology Reviews, 94: 104-117.

Armistead, S.E., Collins, A., Merdith, A.S., Payne, J.L., Cox, G.M., Foden, J.D., Razakamanana, T. and De Waele, B., 2019. Evolving marginal terranes during Neoproterozoic supercontinent reorganisation: constraints from the Bemarivo Domain in northern Madagascar. Tectonics.

Armistead, S.E., Collins, A.S., Payne, J.L., Foden, J.D., De Waele, B., Shaji, E. and Santosh, M., 2017. A re-evaluation of the Kumta Suture in western peninsular India and its extension into Madagascar. Journal of Asian Earth Sciences.

Armstrong, R.L., Jäger, E. and Eberhardt, P., 1966. A comparison of K-Ar and Rb-Sr ages on Alpine biotites. Earth and Planetary Science Letters, 1(1): 13-19.

BGS-USGS-GLW, 2008. Republique de Madagascar Ministère de L'engergie et des Mines (MEM/SG/DG/UCP/PGRM). British Geological Survey Research Report.

Boger, S.D., Hirdes, W., Ferreira, C.A.M., Jenett, T., Dallwig, R. and Fanning, C.M., 2015. The 580-520Ma Gondwana suture of Madagascar and its continuation into Antarctica and Africa. Gondwana Research, 28(3): 1048-1060.

Boger, S.D., Hirdes, W., Ferreira, C.A.M., Schulte, B., Jenett, T. and Fanning, C.M., 2014. From passive margin to volcanosedimentary forearc: The Tonian to Cryogenian evolution of the Anosyen Domain of southeastern Madagascar. Precambrian Research, 247: 159-186.

Boger, S.D., Maas, R., Pastuhov, M., Macey, P.H., Hirdes, W., Schulte, B., Fanning, C.M., Ferreira, C.A.M., Jenett, T. and Dallwig, R., 2019. The tectonic domains of southern and western Madagascar. Precambrian Research.

Chamberlain, K.R. and Bowring, S.A., 20o1. Apatite-feldspar U-Pb thermochronometer: a reliable, mid-range $\left(\sim 450^{\circ} \mathrm{C}\right)$, diffusion-controlled system. Chemical Geology, 172(1): 173-200.

Collins, A.S., 2006. Madagascar and the amalgamation of Central Gondwana. Gondwana Research, 9(1-2):3-16.

Collins, A.S., Fitzsimons, I.C.W., Hulscher, B. and Razakamanana, T., 2003a. Structure of the eastern margin of the East African Orogen in central Madagascar. Precambrian Research, 123(2-4): 111-133.

Collins, A.S., Johnson, S., Fitzsimons, I.C., Powell, C.M., Hulscher, B., Abello, J. and Razakamanana, T., 2003 b. Neoproterozoic deformation in central Madagascar: a structural section through part of the East African Orogen. Geological Society, London, Special Publications, 206(1): 363-379.

Collins, A.S., Kinny, P.D. and Razakamanana, T., 2012. Depositional age, provenance and metamorphic age of metasedimentary rocks from southern Madagascar. Gondwana Research, 21(2-3):353-361.

Collins, A.S., Kröner, A., Fitzsimons, I.C.W. and Razakamanana, T., 2003c. Detrital footprint of the Mozambique ocean: U$\mathrm{Pb}$ SHRIMP and $\mathrm{Pb}$ evaporation zircon geochronology of metasedimentary gneisses in eastern Madagascar. Tectonophysics, 375(1-4): 77-99.

Collins, A.S. and Pisarevsky, S.A., 2005. Amalgamating eastern Gondwana: The evolution of the Circum-Indian Orogens. Earth-Science Reviews, 71(3-4): 229-270.

Collins, A.S., Razakamanana, T. and Windley, B.F., 20oo. Neoproterozoic extensional detachment in central Madagascar: implications for the collapse of the East African Orogen. Geological Magazine, 137(1): 39-51.

Collins, A.S. and Windley, B.F., 2002. The tectonic evolution of central and northern Madagascar and its place in the final assembly of Gondwana. The Journal of Geology, 110(3): 325-339.

Cox, R., Armstrong, R.A. and Ashwal, L.D., 1998. Sedimentology, geochronology and provenance of the Proterozoic Itremo Group, central Madagascar, and implications for pre-Gondwana palaeogeography. Journal of the Geological Society, 155(6): 1009-1024. 
Cox, R., Coleman, D.S., Chokel, C.B., DeOreo, S.B., Wooden, J.L., Collins, A.S., De Waele, B. and Kröner, A., 2004. Proterozoic tectonostratigraphy and paleogeography of central Madagascar derived from detrital zircon U-Pb age populations. The Journal of geology, $112(4): 379-399$.

De Waele, B., Thomas, R.J., Macey, P.H., Horstwood, M.S.A., Tucker, R.D., Pitfield, P.E.J., Schofield, D.I., Goodenough, K.M., Bauer, W., Key, R.M., Potter, C.J., Armstrong, R.A., Miller, J.A., Randriamananjara, T., Ralison, V., Rafahatelo, J.M., Rabarimanana, M. and Bejoma, M., 2011. Provenance and tectonic significance of the Palaeoproterozoic metasedimentary successions of central and northern Madagascar. Precambrian Research, 189(1-2): 18-42.

de Wit, M.J., Bowring, S.A., Ashwal, L.D., Randrianasolo, L.G., Morel, V.P.I. and Rambeloson, R.A., 20o1. Age and tectonic evolution of Neoproterozoic ductile shear zones in southwestern Madagascar, with implications for Gondwana studies. Tectonics, 20(1): 1-45.

Del Moro, A., Puxeddu, M., di Brozolo, F.R. and Villa, I.M., 1982. Rb-Sr and K-Ar ages on minerals at temperatures of $300^{\circ}-$ $400^{\circ} \mathrm{C}$ from deep wells in the Larderello geothermal field (Italy). Contributions to Mineralogy and Petrology, 81(4): 340-349.

Emmel, B., Jons, N., Kroner, A., Jacobs, J., Wartho, J.A., Schenk, V., Razakamanana, T. and Austegard, A., 2008. From Closure of the Mozambique Ocean to Gondwana Breakup: New Evidence from Geochronological Data of the Vohibory Terrane, Southwest Madagascar. The Journal of Geology, 116(1): 21-38.

Fernandez, A., Schreurs, G., Villa, I.M., Huber, S. and Rakotondrazafy, M., 2003. Age constraints on the tectonic evolution of the Itremo region in Central Madagascar. Precambrian Research, 123(2-4): 87-110.

Fitzsimons, I.C.W. and Hulscher, B., 2005. Out of Africa: detrital zircon provenance of central Madagascar and Neoproterozoic terrane transfer across the Mozambique Ocean. Terra Nova, 17(3): 224-235.

Grasemann, B., Wiesmayr, G., Draganits, E. and Fusseis, F., 2004. Classification of refold structures. The Journal of geology, 112(1): 119-125.

Horton, F., Hacker, B., Kylander-Clark, A., Holder, R. and Jöns, N., 2016. Focused radiogenic heating of middle crust caused ultrahigh temperatures in southern Madagascar. Tectonics, 35(2): 293-314.

Jenkin, G.R.T., Ellam, R.M., Rogers, G. and Stuart, F.M., 2001. An investigation of closure temperature of the biotite Rb-Sr system: The importance of cation exchange. Geochimica et Cosmochimica Acta, 65(7): 1141-116o.

Jöns, N., Emmel, B., Schenk, V. and Razakamanana, T., 2009. From orogenesis to passive margin-the cooling history of the Bemarivo Belt (N Madagascar), a multi-thermochronometer approach. Gondwana Research, 16(1): 72-81.

Jöns, N. and Schenk, V., 2008. Relics of the Mozambique Ocean in the central East African Orogen: evidence from the Vohibory Block of southern Madagascar. Journal of Metamorphic Geology.

Jöns, N. and Schenk, V., 2011. The ultrahigh temperature granulites of southern Madagascar in a polymetamorphic context: implications for the amalgamation of the Gondwana supercontinent. European Journal of Mineralogy, 23(2): 127156.

Kröner, A., Hegner, E., Collins, A.S., Windley, B.F., Brewer, T.S., Razakamanana, T. and Pidgeon, R.T., 20oo. Age and magmatic history of the Antananarivo Block, central Madagascar, as derived from zircon geochronology and Nd isotopic systematics. American Journal of Science, 300(4): 251-288.

Macey, P.H., Bisnath, A., Yibas, B., Robson, L. and Andriamanantsoa, E., 2009. Carte Geologique de Madagascar, Council for Geoscience, Pretoria, Afrique du Sud.

Macey, P.H., Thomas, R.J., Grantham, G.H., Ingram, B.A., Jacobs, J., Armstrong, R.A., Roberts, M.P., Bingen, B., Hollick, L., de Kock, G.S., Viola, G., Bauer, W., Gonzales, E., Bjerkgård, T., Henderson, I.H.C., Sandstad, J.S., Cronwright, M.S. Harley, S., Solli, A., Nordgulen, Ø., Motuza, G., Daudi, E. and Manhiça, V., 2010. Mesoproterozoic geology of the Nampula Block, northern Mozambique: Tracing fragments of Mesoproterozoic crust in the heart of Gondwana. Precambrian Research, 182(1-2): 124-148.

Martelat, J.-E., Lardeaux, J.-M., Nicollet, C. and Rakotondrazafy, R., 20oo. Strain pattern and late Precambrian deformation history in southern Madagascar. Precambrian research, 102(1-2): 1-20.

Meert, J.G., Nédélec, A. and Hall, C., 2003. The stratoid granites of central Madagascar: paleomagnetism and further age constraints on neoproterozoic deformation. Precambrian Research, 120(1-2): 101-129.

Merdith, A.S., Collins, A.S., Williams, S.E., Pisarevsky, S., Foden, J.D., Archibald, D.B., Blades, M.L., Alessio, B.L., Armistead, S. and Plavsa, D., 2017. A full-plate global reconstruction of the Neoproterozoic. Gondwana Research, 50: 84-134.

Moine, B., 1968. Massif Schisto-Quartzo-Dolomitique: Reion d'Ambatofinandrahana centre-ouest du socle cristallin precambrien de Madagascar In: N. Sciences de la terre (Editor). Centre de l'Institut Géographique National à Tananarive.

Moine, B., Bosse, V., Paquette, J.-L. and Ortega, E., 2014. The occurrence of a Tonian-Cryogenian ( 85oMa) regional metamorphic event in Central Madagascar and the geodynamic setting of the Imorona-Itsindro ( 80oMa) magmatic suite. Journal of African Earth Sciences, 94: 58-73.

Nédélec, A., Ralison, B., Bouchez, J.L. and Grégoire, V., 200o. Structure and metamorphism of the granitic basement around Antananarivo: A key to the Pan-African history of central Madagascar and its Gondwana connections. Tectonics, 19(5): 997-1020.

Paquette, J.-L. and Nédélec, A., 1998. A new insight into Pan-African tectonics in the East-West Gondwana collision zone by $\mathrm{U}-\mathrm{Pb}$ zircon dating of granites from central Madagascar. Earth and Planetary Science Letters, 155(1-2): 45-56.

Paquette, J.-L., Nédélec, A., Moine, B. and Rakotondrazafy, M., 1994. U-Pb, single zircon Pb-evaporation, and Sm-Nd isotopic study of a granulite domain in SE Madagascar. The Journal of Geology, 102(5): 523-538. 
Poblet, J. and Lisle, R.J., 2011. Kinematic evolution and structural styles of fold-and-thrust belts. Geological Society, London, Special Publications, 349(1): 1-24.

Raharimahefa, T. and Kusky, T.M., 2006. Structural and remote sensing studies of the southern Betsimisaraka Suture, Madagascar. Gondwana Research, 10(1-2): 186-197.

Raharimahefa, T. and Kusky, T.M., 2009. Structural and remote sensing analysis of the Betsimisaraka Suture in northeastern Madagascar. Gondwana Research, 15(1): 14-27.

Raharimahefa, T. and Kusky, T.M., 2010. Temporal evolution of the Angavo and related shear zones in Gondwana: Constraints from LA-MC-ICP-MS U-Pb zircon ages of granitoids and gneiss from central Madagascar. Precambrian Research, 182(1-2): 30-42.

Raharimahefa, T., Kusky, T.M., Toraman, E., Rasoazanamparany, C. and Rasaonina, I., 2013. Geometry and kinematics of the late Proterozoic Angavo Shear Zone, Central Madagascar: Implications for Gondwana Assembly. Tectonophysics, 592: 113-129.

Roig, J., Tucker, R., Delor, C., Peters, S. and Théveniaut, H., 2012. Carte géologique de la République de Madagascar à 1/1 ooo ooo, Ministère des Mines, PGRM, Antananarivo, République de Madagascar.

Schoene, B. and Bowring, S.A., 2007. Determining accurate temperature-time paths from U-Pb thermochronology: An example from the Kaapvaal craton, southern Africa. Geochimica et Cosmochimica Acta, 71(1): 165-185.

Schofield, D.I., Thomas, R.J., Goodenough, K.M., De Waele, B., Pitfield, P.E.J., Key, R.M., Bauer, W., Walsh, G.J., Lidke, D.J. and Ralison, A.V., 2010. Geological evolution of the Antongil Craton, NE Madagascar. Precambrian Research, 182(3): 187-203.

Service Géologique de Madagascar, T., 1962. Moramanga-Brickaville.

Service Géologique de Madagascar, T., 1963a. Antsirabe-Ampatolampy

Service Géologique de Madagascar, T., 1963b. Miarinarivo-Tanarive.

Thomas, R.J., De Waele, B., Schofield, D.I., Goodenough, K.M., Horstwood, M., Tucker, R., Bauer, W., Annells, R., Howard, K., Walsh, G., Rabarimanana, M., Rafahatelo, J.M., Ralison, A.V. and Randriamananjara, T., 2009. Geological evolution of the Neoproterozoic Bemarivo Belt, northern Madagascar. Precambrian Research, 172(3-4): 279-300.

Tucker, R., Ashwal, L., Handke, M., Hamilton, M., Le Grange, M. and Rambeloson, R., 1999. U-Pb geochronology and isotope geochemistry of the Archean and Proterozoic rocks of north-central Madagascar. The Journal of Geology, 107(2): 135-153.

Tucker, R., Roig, J.-Y., Delor, C., Amelin, Y., Goncalves, P., Rabarimanana, M., Ralison, A. and Belcher, R., 2011. Neoproterozoic extension in the Greater Dharwar Craton: a reevaluation of the "Betsimisaraka suture" in Madagascar. Canadian Journal of Earth Sciences, 48(2):389-417.

Tucker, R.D., Kusky, T.M., Buchwaldt, R. and Handke, M.J., 2007. Neoproterozoic nappes and superposed folding of the Itremo Group, west-central Madagascar. Gondwana Research, 12(4): 356-379.

Tucker, R.D., Roig, J.Y., Moine, B., Delor, C. and Peters, S.G., 2014. A geological synthesis of the Precambrian shield in Madagascar. Journal of African Earth Sciences, 94: 9-30.

Verschure, R.H., Andriessen, P.A.M., Boelrijk, N.A.I.M., Hebeda, E.H., Maijer, C., Priem, H.N.A. and Verdurmen, E.A.T., 1980. On the thermal stability of Rb-Sr and K-Ar biotite systems: Evidence from coexisting Sveconorwegian (ca 870 $\mathrm{Ma}$ ) and Caledonian (ca $400 \mathrm{Ma}$ ) biotites in SW Norway. Contributions to Mineralogy and Petrology, 74(3): 245252. 